\title{
INTERDISCIPLINARIDADE - TRANSDISCIPLINARIDADE NOS ESTUDOS URBANOS
}

\author{
v. 7, n. 10 \\ jan/ago (2015) \\ ISSN 1982-0569
}

\author{
Maria Stella Bresciani \\ Centro Interdisciplinar de Estudos sobre a Cidade / CIEC-UNICAMP \\ e-mail: sbrescia@lexxa.com.br
}

\begin{abstract}
Resumo
Este artigo tem por objetivo propor um debate sobre as possíveis leituras das cidades contemporâneas, em particular, o modo como se estruturam as críticas às gigantescas metrópoles, as megalópoles. A capital paulista foi o ponto de partida que ensejou uma reflexão sobre a persistência de noções do campo conceitual do urbanismo formuladas no decorrer do século XIX e início do século XX. Nos dias atuais merecem a atenção da mídia televisiva e escrita os congestionamentos quilométricos e a violência em várias formas, projetos de revitalização de áreas frente a resistência de moradores e parte dos profissionais da área de arquitetura e urbanismo, a ocupação de áreas de risco e de proteção ambiental. Destaca-se a heterogeneidade dos bairros, a polarização que segrega a população pobre nas zonas das margens do território urbanizado, as denominadas periféricas, e nos enclaves de favelas e cortiços intraurbanos, a fragmentação estilística da arquitetura, a ausência de marcos simbólicos dotados de significado coletivo. Nossa intenção foi acompanhar os caminhos de algumas propostas e execução de intervenções em cidades europeias e nelas surpreender as noções que em sua formação receberam aportes da medicina e da engenharia, mas também dos filantropos, filósofos e até de biólogos, como Patrick Geddes, e expor a rede transdisciplinar que constituiu o campo do urbanismo. E mais, sugerir sua permanência ainda nos dias de hoje.
\end{abstract}

\section{Palavras-chave}

Interdisciplinaridade, Transdisciplinaridade, Urbanização/Urbanismo, Metrópoles/megalópoles, Segregação, Periferia

\begin{abstract}
This paper proposes a debate on the possible readings of contemporaneous cities, especially the way criticisms of gigantic metropolises, the so called megalopolises, are structured. The capital of the state of Sao Paulo is the starting point of a reflection on the persistence of notions from the conceptual field of urban studies formulated during the $19^{\text {th }}$ and the beginning of the $20^{\text {th }}$ centuries. Nowadays, TVs and the printed press focus on traffic jams and different forms of violence, projects to revitalize areas due to the resistance of dwellers and part of professionals in the fields of architecture and urbanism, and the occupation of risk and environmental protection areas. The text highlights the heterogeneity of neighborhoods, the polarization that segregates the poor into marginal, peripheral areas of the urbanized territory and enclaves of intra-urban slums and tenements, the stylistic fragmentation of architecture, and the lack of symbolic landmarks with collective meanings. It follows the steps of some proposals and interventions executed in European cities to unveil notions that, in their formation, were contributions from not only doctors and engineers, but also philanthropists, philosophers and even biologists, as Patrick Geddes, and expose the transdisciplinary network that has constituted the field of urban studies to suggest it is still present today.
\end{abstract}

\section{Keywords}

Interdisciplinarity, Transdisciplinarity, Metropolis/Megalopolis, Urbanization - Urbanism, Segregation, Periphery areas 


\section{Interdisciplinaridade - Transdisciplinaridade nos Estudos Urbanos ${ }^{1}$}

A mídia em geral e, se considerado um recorte mais limitado, a imprensa, trazem quase sempre matérias críticas sobre o cotidiano na cidade de São Paulo: congestionamentos quilométricos, violência em várias formas, projetos de revitalização de áreas frente a resistência de moradores e parte dos profissionais da área de arquitetura e urbanismo, ocupação de áreas de risco e de proteção ambiental. Culpase a administração pública, o traçado urbano radial-concêntrico, o descaso dos próprios moradores com as áreas de uso comum, a heterogeneidade dos bairros, a polarização que segrega a população pobre nas zonas das margens do território urbanizado, as denominadas periferias, e nos enclaves de favelas e cortiços intraurbanos, a fragmentação estilística da arquitetura, a ausência de marcos simbólicos dotados de significado coletivo. Só é possível ter opinião positiva sobre a cidade quando o assunto é negócios, arte e cultura, ainda que, a totalidade da população, certamente, não tenha acesso aos museus, teatros e salas de eventos. Seriam essas as característica da cidade de São Paulo?

\section{Qual a leitura possível das cidades contemporâneas?}

Em livro publicado em 2000, Bernardo Secchi, engenheiro e professor de urbanismo da Universidade de Veneza observava:

As respostas às características e aos problemas da cidade contemporânea têm sido até agora muito variadas; tanto que fica difícil, mesmo sob pena de certa simplificação, mapeá-las. Uma primeira posição é aquela de quem pensa a cidade contemporânea e a cidade industrial, que imediatamente a precedeu, como formas degradadas da cidade moderna, como simples desvio da linha de desenvolvimento e dos equilíbrios alcançados pela cidade ocidental no fim do século XVIII, e propõe a eles retornar: recusa da heterogeneidade, da aproximação paratática do fragmento (Secchi, 2000, p. 117).

Secchi repetiria em livro publicado em 2005 que os aspectos fundamentais da cidade nesse início do século XXI, tais como visualizados por estudiosos especializados em várias disciplinas e citadinos em geral, estariam relacionados ao fragmento, à heterogeneidade e à dispersão. Critica esse olhar por considerá-lo projeções do medo,

\footnotetext{
${ }^{1}$ Em sua versão preliminar, este artigo foi apresentado como conferência no XXVI Simpósio Nacional de História. ANPUH: 50 anos em 2011. Agradeço à Maria Cristina Schicchi, à Marisa Carpintéro e à Josianne Cerasoli pelas leituras e sugestões e à Clecia Gomes pelo apoio logístico com as imagens. Esse texto é resultado parcial da pesquisa financiada pelo CNPq. 
da imaginação em contínuo confronto com o cotidiano; olhar cuja imagem da cidade do passado desenha-se no registro da nostalgia, da crítica severa e do estranhamento (Secchi, 2006, p. 9).

A dificuldade de se situar no presente levaria ao desejo de volta à situação anterior, à vontade de reproduzir o passado que, por ser anacrônica, viola o decurso do tempo. Sua afirmação é taxativa ao dizer da impossibilidade de reviver ou fazer sobreviver ideias, tradições e modos de construir que se opõem ao sentido das práticas sociais. O engenheiro vai mais longe e, ao explicitar, cita o exemplo dos puristas de Siena entre os séculos XIX e XX:

(...) o restauro é muitas vezes falsificação do anacronismo que, com a idade, caracteriza todo edifício e toda cidade; a preservação torna-se (....) mera invenção de um passado imaginado e que nunca existiu, bastidores de uma cena urbana esvaziada de conteúdo, da qual foram eliminados os odores, os rumores, os riscos de incêndio, a proximidade e a promiscuidade, a sujeira e a escuridão da cidade medieval (Secchi, 2006, p. 118).

Considerar as cidades contemporâneas inóspitas, violentas quando não degradadas, compará-las a um período anterior, por vezes, não muito distante, tornouse moeda corrente. Certamente, a experiência no dia-a-dia dos habitantes de grandes cidades envolve, tal como em São Paulo, problemas de não pouca monta. Medo da violência presumida e transtornos diversos nos deslocamentos entre casa e trabalho constituem partes da dimensão negativa do viver em grandes cidades. Os estudiosos do urbanismo e demais especialistas em questões urbanas, de seu lado, expõem continuamente a inversão do sentido original presente nas práticas de intervenção, remodelação e reurbanização de áreas já constituídas e do processo de urbanização de novas áreas. Por outro lado, várias pesquisas têm se dedicado a compreender as formas de inserção do habitante na cidade contemporânea e sua percepção do significado de se viver em sociedades de fluxo. ${ }^{2}$

As críticas convergem para o lugar-comum que causa certo desconforto pela banalização - afirma-se haver uma distância entre técnicos especializados aliados a autoridades públicas e os habitantes. Pesquisas de recortes espaciais específicos possibilitam verificar quando e como as intervenções se deram por meio de dispositivos

\footnotetext{
2 Para ampliar o debate sobre a percepção das cidades contemporâneas, aqui colocado pelas palavras de Secchi, remeto para os excelentes trabalhos de Boyer (1966) e Arenas (2011).
}

REVISTA ELETRONICA DO CENTRO INTERDISCIPLINAR DE ESTUDOS SOBRE A CIDADE . ISSN 1982-0569 v. 7, n. 10, jan /ago (2015). Dossiê História Urbana: a configuração de um campo conceitual 
ClEC

prescritos pelos legisladores apoiados no saber dos especialistas e pressionados por interesses de empresas imobiliárias, resultando em soluções supostamente apartadas dos interesses e das necessidades dos próprios habitantes. Este procedimento daria lugar, afirmam, a um afastamento progressivo de parcela significativa dos citadinos e levaria em diversas oportunidades à resistência ou à recusa, e a práticas alternativas, em geral à revelia da lei, de ocupação do solo e de urbanização selvagem, situação verificada na maioria das cidades, em particular nas grandes metrópoles.

Minha proposta é a de verificar o quanto essa avaliação crítica está também presente nos estudos sobre São Paulo: qual(is) seria(m) seu(s) foco(s) e os argumentos utilizados na defesa de posições nem sempre coincidentes.

\section{Urbanistas na grande imprensa}

Em 19 de junho de 2011, uma matéria publicada no caderno Aliás do Estadão Horizontes urbanos. Os dilemas e os rumos da metrópole que potencializa os problemas das principais cidades brasileiras - trouxe entrevistas de três urbanistas com longa trajetória profissional: Ermínia Maricato, Cândido Malta Campos e Jorge Wilheim. Suas respostas convergem em observações negativas acerca das várias dimensões das condições de vida na cidade de São Paulo, embora nem sempre sejam coincidentes. A tônica da defasagem da infraestrutura em relação a cidades do "Primeiro Mundo", o compartilhamento de problemas estruturais com cidades contemporâneas, tais, como Buenos Aires, Cidade do México, Johannesburgo, divididas entre a cidade formal e a cidade informal, se somam à pobreza, violência e atraso. Para Maricato, o enquadramento mais amplo da situação expõe os problemas herdados do recente período pós-liberal com a retração das políticas públicas.

Wilheim explica "o atraso" em recuo para o século XIX quando ainda vigente a escravidão, e relaciona a resistência de alguns moradores de Higienópolis à instalação de uma estação do metrô no bairro ao "sentimento de privilégio herdado de um Portugal medieval". Os entrevistados não deixam de lembrar a área central da cidade, denominada pejorativamente de "cracolândia" em suas tristes imagens de pequenos traficantes em meio a drogados e perguntam: "O urbanismo tem ferramentas para mitigar essa tragédia social?" As respostas não oferecem um "abre-te sésamo", porém explicitam as diferentes posições dos urbanistas. Somente Maricato afirma ser necessário investir na recuperação das pessoas em vista do enorme crescimento da 
população de rua na capital paulista, "alguns com nível universitário, até família inteiras", cujo número de 8.706 pessoas em 2000 subiu para 13.666 em 2009. Já Wilheim considera que a questão pertence ao campo da saúde pública e não dispor o urbanista de ferramentas para lidar com o problema. Diversidade de opiniões que se repete em relação ao que se considera necessário para a "revitalização" da área segundo as diretrizes do polêmico projeto "Nova Luz" cuja "missão", segundo o Portal da Prefeitura Municipal, seria a de "definir as bases para a requalificação da região" de cerca de 500 mil m² com cerca de 11.600 moradores que abriga duas estações ferroviárias, a Júlio Prestes, hoje sala São Paulo, e a Luz, junção de ferrovia e metrô, e que também abriga o Museu da Língua Portuguesa, a Pinacoteca do Estado e a Estação Pinacoteca, além de ter próximo, o Museu de Arte Sacra. A proposta de revitalização da área, em recorte limitado, conhecida como Cracolândia, projeta a construção do Complexo Cultural Tom Jobim - Teatro de Dança e da Escola de Música do Estado -e a companhia da dança e a demolição de parte substancial de antigas edificações. ${ }^{3}$ Enquanto para Maricato seria desejável e possível manter os que lá vivem e/ou tiram seu sustento do comércio e, ao mesmo tempo, garantir financiamento para construir e dar acesso a "moradia para um mix de classe média e média baixa no centro", Wilheim e Campos entendem que "toda melhoria urbana resulta em algum deslocamento de moradores" e até consideram que essa "exclusão social, decorrerá da preferência dos moradores em obter moradia em Zonas Especiais de Interesse Social", as ZEIS. Wilheim avalia o Plano Urbanístico para a área como "da mais alta qualidade técnica e, [que] se implantado ... poderá se constituir em uma inflexão altamente positiva para a cidade".

Reconhecem existirem também problemas que constituem desafios atuais para as grandes metrópoles do (assim chamado) "Primeiro Mundo": o crescimento extensivo e disperso da área urbanizada da capital paulista apresenta-se como problema cuja solução estaria na aplicação do conceito de "cidades compactas", discutido no C40 São Paulo Summit 2011.4 De forma complementar, Wilheim aponta a polinucleação de cidades grandes como diretriz de bom senso definida no Plano Diretor de 2002 e interrompida, entretanto, com a mudança de prefeito em 2004. Na mesma linha argumentativa, para Campos, áreas como a "Zona Leste, com 4 milhões de habitantes,

\footnotetext{
${ }^{3}$ Informações encontram-se no Portal da Prefeitura [prefeitura.sp.gov.br], Operações Urbanas - Nova Luz.

${ }^{4}$ Evento bianual, sediado em sua quarta edição em São Paulo pelo C40 Cities Climate Leadership Group (organização as maiores cidades do mundo em torno de políticas sustentáveis para atenuar o aquecimento global). 
comporta[m] uma centralidade regional". Maricato se estende mais na resposta e afirma ser unanimidade entre os urbanistas o movimento em direção às cidades compactas, principalmente entre os europeus que condenam os subúrbios [norte]americanos, dispersivos e extensivos. Para ela, constituem problemas, tanto, a situação irregular de dispersão da população de baixa renda pela periferia, como os condomínios fechados de alta renda, processo que encontraria sua explicação por "estarmos na periferia do capitalismo", sem o devido controle do uso do solo pelo Estado.

Frente ao abandono de áreas centrais esvaziadas e degradadas, os três entrevistados concordam ser adversa a urbanização dispersiva. Maricato vai além da afirmação da necessidade de revitalização e requalificação das áreas centrais ao defender serem locais apropriados à construção de moradias para famílias de média e baixa renda, posição também defendida pelos movimentos sociais, pois essas áreas dispõem de edifícios ociosos que não cumprem a função social da propriedade prevista na Constituição de 1988. Os três urbanistas condenam os condomínios fechados como resposta à violência efetiva ou potencial, por configurarem a anti-cidade, e denunciam a ilegalidade dos loteamentos fechados no entorno das Regiões Metropolitanas de São Paulo, Campinas e Santos.

Quanto a exemplos de soluções de outras metrópoles exequíveis em nossas cidades, as respostas vão da preferência de Wilheim por uma São Paulo assemelhada a Paris, embora por ser uma cidade americana, reconheça sua maior semelhança com Nova York, mas com o foco nas sociais democracias da Europa examina ainda exemplos de propriedades semipúblicas, preferência compartilhada por Campos. Na contramão deles, Maricato critica a busca de modelos no Primeiro Mundo, pois a considera vício da má tradição brasileira. Em suma, segundo o comentarista Washington Novaes, em artigo de 15 de julho do mesmo ano, os três urbanistas concordam ser preciso planejar intervenções urbanas substanciais; ser fundamental superar o modelo rodoviarista; ser indispensável valorizar os espaços de convivência coletiva "na lógica contrária à dos bunkers privados" (Novaes, O Estado de S. Paulo, 15 jul. 2011).

Com certeza, a matéria acima comentada é jornalística e as respostas, rápidas e curtas, destinam-se a um público amplo e não especializado. Assim, para melhor situar as questões, considerei imprescindível recorrer a uma publicação especializada, e para 
tanto, tomei o dossiê editado por Alfredo Bosi, São Paulo, hoje da revista Estudos Avançados USP 25 (71), de janeiro/abril 2011.

\section{Avaliações em escritos universitários}

Em São Paulo, hoje, os artigos enviados para publicação entre fevereiro e março de 2011 compõem um conjunto de resultados de pesquisas acadêmicas, com argumentos fundamentados em dados quantitativos e análises qualitativas e fornecem subsídios importantes para compreendermos a condição atual de São Paulo, de várias cidades brasileiras e latino-americanas. No geral, os autores apresentam recortes de um amplo e complexo panorama de problemas da cidade e em suas análises se apoiam em noções e conceitos diferenciados e referidos ao específico tema proposto.

A Região Metropolitana com seus 38 municípios e 19.672.582 habitantes (Censo de 2010) constitui o recorte espacial. Esses números demonstram, afirma Martins (2011, p.59), estarmos frente a "uma cidade nova, erguida em 70 anos", já que a região contava com 1.568.045 habitantes em 1940. Seria muito longo comentar todos os artigos do dossiê, bem como a formação acadêmica e as diferentes opções teóricas dos autores. Pode-se, contudo, afirmar o reconhecimento unânime de um processo cujo cerne está no "modelo de desenvolvimento urbano" em íntima correlação com a "desigualdade e injustiça social" geradora da "segregação espacial", e suas consequências desafiantes em diversas dimensões - social, econômica, política e cultural. A questão central desdobra-se na relação homem/sociedade e natureza, visualizada pela ocupação irregular das "franjas periféricas" que pressionam áreas de preservação ambiental e a especulação imobiliária que mantém edifícios desocupados na área central da cidade; pelo "stress" hídrico ocasionado com usos inadequados da água e problemas de seu gerenciamento; pela má gestão dos resíduos sólidos e líquidos e a pouca atenção dos poderes públicos em relação à implantação e preservação de áreas não edificadas a serem oferecias à população como espaços livres - ruas, praças e parques. 


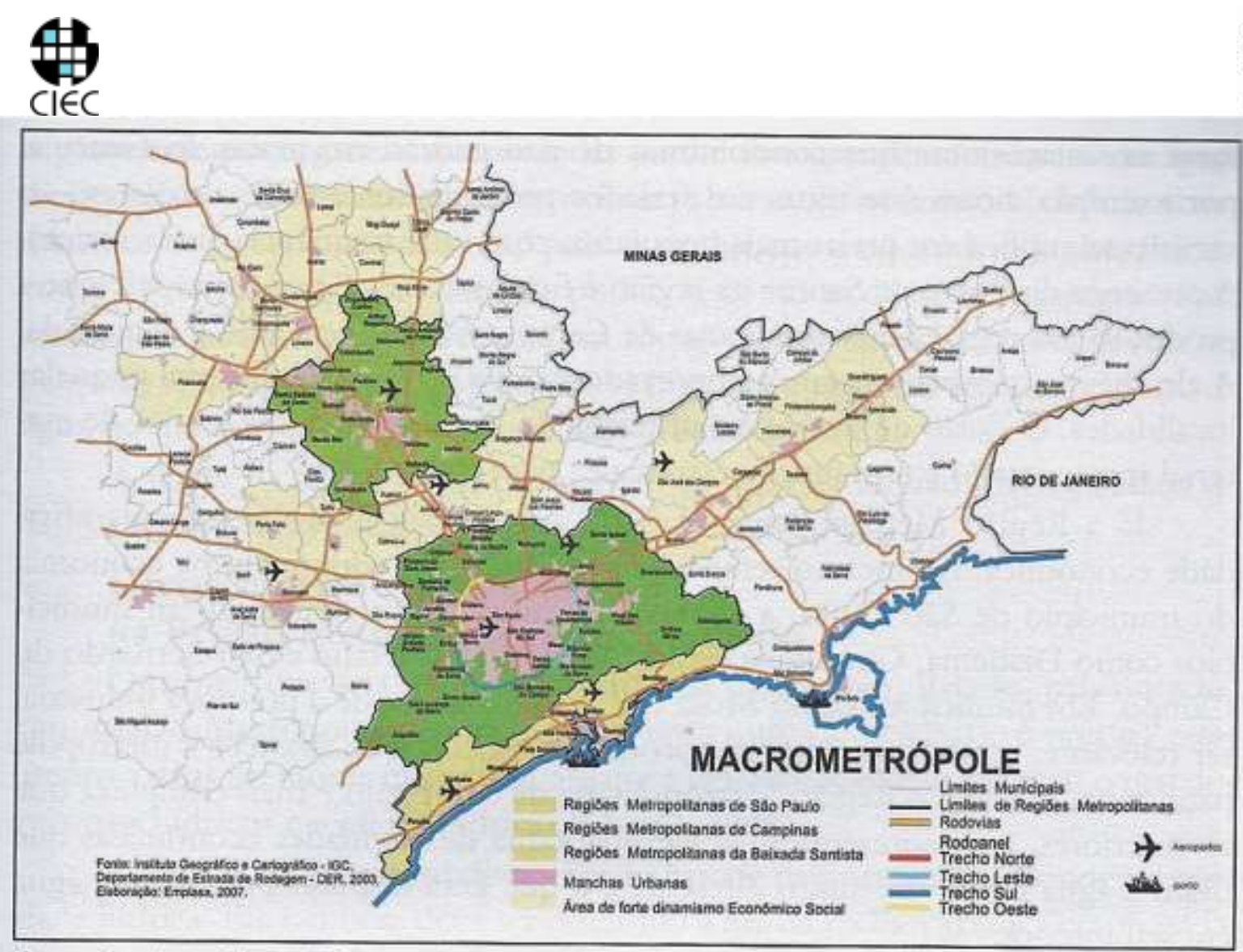

Fonte: Emplasa. Disponível em: <http://www.emplasa.sp.gov.br.htm>.

Figura 1: Mapa da Macrópole paulista (Ribeiro, 2011, p. 121).

Embora as análises da situação atual sejam negativas, parte dos autores sugere políticas públicas e técnicas com o intuito de reverter o quadro: medidas para a requalificação de áreas degradadas centrais e periféricas, o adensamento da ocupação com qualidade ambiental das áreas providas de equipamentos urbanos de modo a dar resposta satisfatória à questão maior da "moradia social", a atenção continuada e coerente de planos de preservação do patrimônio edificado como "lugares de memória", e a gestão integrada e sustentável dos resíduos sólidos e líquidos, captação e distribuição de água.

Escolhi alguns artigos cujo recorte de problemas básicos permite apreender a questão urbana contemporânea e sua enorme complexidade: a escala da pesquisa estendida à região metropolitana, o transporte individual e coletivo em sua relação com as vias de superfície e subterrâneas, a requalificação do centro, o patrimônio edificado e sua preservação. Neles me detenho no campo conceitual que apoia as análises e na avaliação resultante do percurso analítico proposto. 
De modo geral, há concordância entre os autores sobre a noção de segregação espaço-social, usualmente expressa na polarização centro-periferia, porém criticada por Flávio Villaça (2011, p.37-58) que a considera limitada, por que também a localiza nos bairros intramuros da cidade. ${ }^{5}$ Desencontros são também significativos se considerada a projeção otimista de reestruturação da cidade formulada por Nabil Bonduki (2011, p. 23-36) e as projeções pessimistas sem horizonte de políticas públicas destinadas a resolver, seja, o "caos" urbano das "Metrópoles desgovernadas", expressa na avaliação de Ermínia Maricato (2011, p. 7-22), ou os impasses da circulação viária, marcada por um modelo ultrapassado, projetado e implantado inicialmente na década de 1930, qualificados por Rolnik e Klintowitz como "crise de mobilidade" (2011, p. 89-108), ou ainda os resultados controversos das intervenções para a requalificação do centro, na opinião de Alves (2011, p. 109-118).

O artigo de Maricato abre o dossiê e apresenta a reflexão mais ampla e geral sobre a urbanização da capital paulista (Maricato, 2011, p. 7-22). Apoiada em ampla bibliografia orientada pelos postulados da CEPAL, ela define a formação da América Latina em "unidades contraditórias" como resultado do "desenvolvimento moderno do atraso", marco de um processo "desigual e combinado". A autora reitera o argumento enunciado na entrevista ao Caderno Aliás do Jornal O Estado de São Paulo, mencionada anteriormente, e afirma ser a situação em parte decorrente de "nossa tradição de buscar nossos modelos no Primeiro Mundo", o que faz a "tarefa de elaborar uma teoria da urbanização na periferia do capitalismo ficar longe de apresentar resultado satisfatório". Essa premissa conceitual pré-dispõe os argumentos de sua análise e das conclusões, já que, para ela, os maus resultados explicam-se pelos "indefectíveis e onipresentes modelos de projetos urbanísticos e arquitetônicos buscados no exterior por qualquer governante de plantão ou pela mídia local, fortemente submetidos ao mimetismo cultural" (Maricato, 2011, p. 8-9).

Sua análise dedica um recorte privilegiado às favelas por nelas predominarem o padrão habitacional de domicílios congestionados e insalubres, sem água potável, esgotos e coleta de lixo, com baixa taxa de emprego e altos níveis de violência.

\footnotetext{
${ }^{5}$ Em posição contrastante à polarização centro-periferia, Flávio Villaça (ANO, p.37-58) trabalha com mapas produzidos por várias instituições de pesquisa de modo a demonstrar a segregação interna, visível na concentração de padrões de vida considerados de alto nível na região sudoeste do município. Seriam avaliações qualitativas feitas a partir de noções apoiadas por estatísticas sobre a menor vulnerabilidade social, com no máximo $10 \%$ de negros (sic) e melhores locais para jovens, o menor número de óbitos por habitante, a temperatura mais amena, o melhor índice de desenvolvimento humano e a renda domiciliar média. Trata-se de zonas exclusivamente residenciais com moradias unifamiliares (Z1.5).
} 
Considera-as "verdadeiras bombas socioecológicas". ${ }^{6}$ Entretanto, afirma, "em que pese a urgência, a questão metropolitana não sensibiliza nenhuma força política ou instituição que lhe atribua lugar de destaque na agenda nacional" (Maricato, 2011, p. 8, 22). Ao contrapor a urbanização periférica da pobreza à urbanização dispersa característica dos subúrbios [norte]americanos, também aqui entende ser equivocado o recurso a noções de uso corrente nas análises urbanísticas, tais como, "metropolização expandida, fragmentação, dispersão, cidades regiões, corredores urbanos, urbanização do arquipélago", pois, a seu ver, não resistem à aplicação empírica nos estudos de nossas cidades. Reafirma ser esse um recurso fruto da "tradição histórica de subordinação cultural" em seu acolhimento pela produção acadêmica (Maricato, 2011, p. 8-9). A autora não apresenta, contudo, estudo comparativo, nem fica evidente em sua análise a inadequação do recurso analítico a essas noções quando se estudam problemas referentes às megalópoles de urbanização dispersa, significativamente presentes na expansão horizontal da mancha urbana de aproximados $200 \mathrm{~km}$ como dilataçãoo da macrópole paulistana foco da atenção de vários estudiosos, dentre os quais Nestor Goulart Reis Filho.7

Na contracorrente de Maricato, Nabil Bonduki analisa o desenvolvimento urbano de São Paulo na escala do município e sua região metropolitana e se apoia, exatamente, na noção de "espraiamento horizontal". Tal como a quase totalidade dos autores, compõe uma imagem negativa deste início do século XXI: "a cidade caminha para o caos", para ele gerado em grande parte pela expansão física sem solução de continuidade entre a capital e os municípios da Região Metropolitana, a urbanização quase ininterrupta entre a baixada Santista e Campinas, espraiada na conurbação de São José dos Campos e de Sorocaba (Bonduki, 2011, p. 23-27). Propõe reverter essa tendência de expansão, fruto de "mera prática tecnocrática e burocratizada". Sua opção teórica leva-o a formular a aposta otimista de "recuperar a dimensão utópica do urbanismo" no intuito de fazer da população uma aliada na "substancial alteração do quadro atual (...) de desigualdade urbana, funcional e social gerando uma cidade partida e segregada". Para Bonduki, rever a política pública que permitiu formar "uma mancha urbana [que] se expande horizontalmente destruindo áreas de proteção

\footnotetext{
${ }^{6}$ A favelização de grandes espaços urbanos mereceu um extenso trabalho de Davis (2006).

${ }^{7}$ Nestor Goulart Reis tem estudado a cidade brasileira desde seus tempos coloniais e estende suas pesquisas à época atual (Reis, 2006).
} 
ClEC

ambiental" constitui tarefa primordial. Reverter a tendência geradora de "assentamentos precários distantes e carentes de infraestrutura e (...) condomínios fechados de média e alta rendas acessíveis apenas por meio do automóvel" e a "verticalização de baixa densidade populacional na área consolidada". Um urbanismo incompatível com o transporte coletivo (Bonduki, 2011, p. 23-36).

Na mesma direção da valorização de bens edificados contraposta à expansão urbana, Silvia Helena Zanirato (2011, p. 189-204) vincula as dificuldades das ações de tombamento ao "desaparecimento do patrimônio cultural material da cidade" e suas implicações para o "sentimento de enraizamento do sujeito com o espaço que habita". Novamente, os interesses divergentes de proprietários e instituições fundadas para proteger bens patrimoniais da cidade aparecem em conflito, resultando muitas vezes em descuido e comprometimento das edificações. Conflitos impeditivos da recuperação de edificações e da "requalificação do centro", ações que poderiam reverter a situação das "áreas ditas decadentes e deterioradas", e assim denominadas, explicita Glória da Anunciação Alves, por terem sido, quando construídas, exatamente o oposto "representavam o auge, a modernização, a pulsão da cidade" até a década de 1950 (Alves, 2011, p. 109-118).

A opção pelas "Operações Urbanas" merece também de Alves uma análise crítica por flexibilizar a legislação urbanística de modo a atrair investimentos que nem sempre atingem seus objetivos, como o da remodelação do Vale do Anhangabaú e do Boulevard São João. Opinião divergente da exposta por Fábio Mariz Gonçalves que advoga a possibilidade de bons resultados se aberto o diálogo com a população local e, para tanto, oferece o exemplo da Vila Sônia, cujo projeto, iniciativa de uma Operação Urbana Consorciada, trouxe benefícios ao invés das poucas melhorias na área obtidas com as intervenções realizadas pela prefeitura (Gonçalves, 2011, p. 205-217).

Dentre os maiores problemas enfrentados pelas megalópoles, para além das moradias precárias nos interstícios de bairros consolidados e em áreas de risco, os obstáculos à mobilidade e deslocamentos se apresentam para os autores como uma questão crucial para os habitantes da metrópole paulistana. Afinal, assinalam os autores, grande parte desses problemas constitui o resultado de um plano urbanístico para a cidade formulado na década de 1920. Essa dimensão abrangente do plano recebe também críticas de Raquel Rolnik e Danielle Klintowitz (2011, p. 89-108), por configurar a opção pelo modelo rodoviarista inscrito na "grelha radioperimetral" do Plano de 
Avenidas de 1930, assinado por Francisco Prestes Maia. Plano confirmado na década de 1950 por Robert Moses em sua proposta para que as avenidas marginais aos rios Tietê e Pinheiros recebessem o tráfego das rodovias. Opção mais uma vez mantida em 1956, quando Prestes Maia, a despeito de haver elaborado um "Anteprojeto de um Sistema de Transporte Rápido Metropolitano" defendeu a prioridade da implantação do segundo anel perimetral (2011, p. 93). Para as autoras, fixado o padrão viário de anéis perimetrais e de "rodovias urbanas", o atual Rodoanel e a ampliação das duas avenidas marginais "favorecem a abertura de frentes de expansão imobiliária de alta renda", sem o correlato investimento em transportes coletivos. (Rolnik e Klintowitz, 2011, p. 98106).

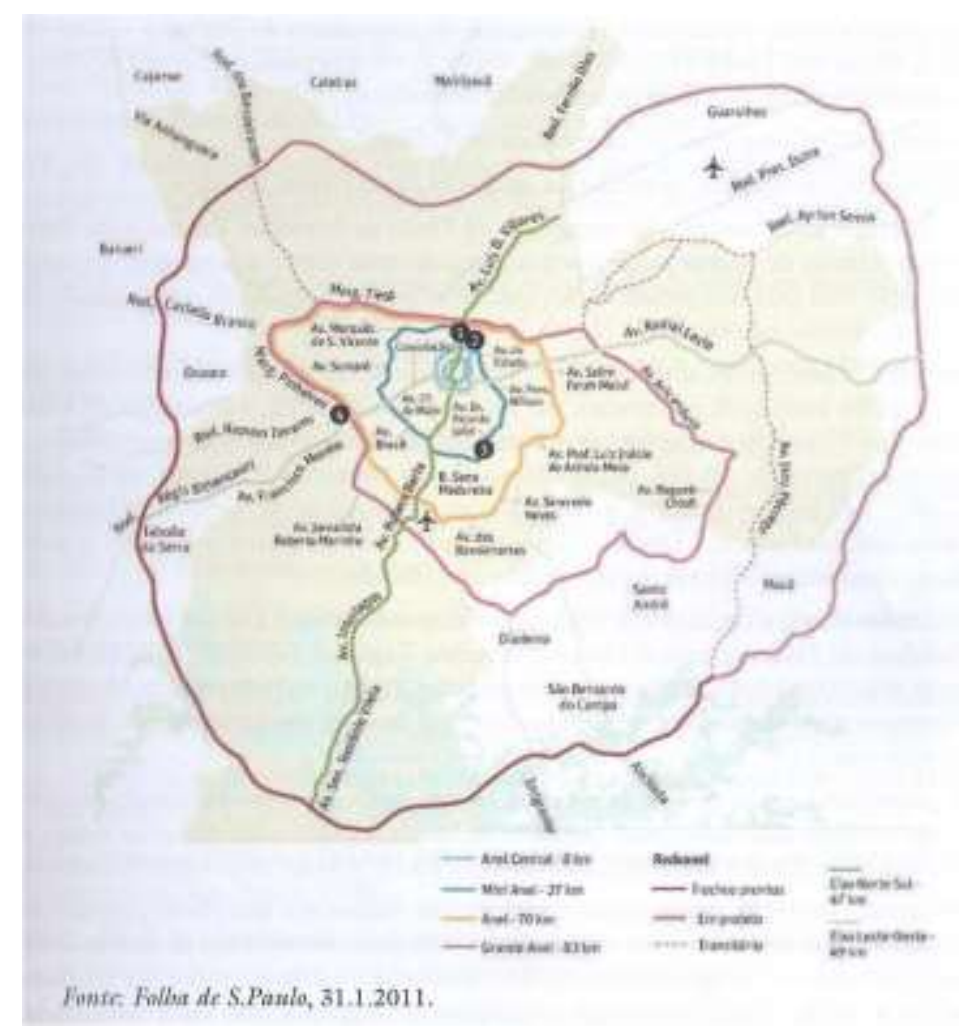

Figura 2: Sistema de anéis viários proposto pela prefeitura para a cidade de São Paulo em janeiro de 2011 (Rolnik e Klintowitz, 2011, p.105). [talvez essa seja uma imagem que possa ser retirada. Afinal o texto não se debruça diretamente sobre essas questões, elas aparecem como forma de mapear o percurso de discussão das autoras]

Ao avaliarem negativamente os resultados do plano viário conformador do tecido urbano paulistano, Rolnik e Klintowitz aproximam-se da proposta de Bonduki de reverter o padrão de urbanização da Região Metropolitana, que para o autor implicaria em adotar políticas públicas que enfrentem "oito desafios-síntese": a reestruturação do 
transporte coletivo, o "crescimento para dentro" e, consequente reversão do esvaziamento do centro expandido e de vários bairros consolidados, estímulos à inclusão social, a criação de novas centralidades, a regularização e urbanização dos loteamentos irregulares e de favelas nas áreas periféricas, a requalificação de espaços públicos. Iniciativas que, reconhece, exigem determinação do poder político, por serem às vezes medidas impopulares que contrariam interesses econômicos (Rolnik e Klintowitz, 2011, p. 29).

Penso ser interessante registrar que, ao propor conter o crescimento horizontal da cidade, Bonduki considera essencial formar e consolidar um cinturão verde "ocupado com atividades produtivas e rentáveis, compatíveis com a preservação ambiental" - de modo a impedir que a RMSP se conurbe integralmente (Bonduki, 2011, p.30). Essa proposta reedita estratégia já defendida no final dos anos 1920 por Luiz de Anhaia Mello, ${ }^{8}$ perdedora nos longos anos de debates com seu colega e também urbanista Prestes Maia. Talvez por isso, Bonduki, Rolnik e Klintowitz direcionem suas críticas ao que denominam de "tristemente famoso" Plano de Avenidas de Prestes Maia, e seus desdobramentos, agora com o Rodoanel. Surpreende, entretanto, encontrar no conjunto de artigos que compõem o dossiê a ressonância, ou melhor, a persistência de campos conceituais formados e vigentes no início do século $X X$ e desdobrados em meados do século, por serem conceitos cujos sentidos se formaram no longo processo de formulação da questão urbana e da disciplina urbanismo no decorrer do século XIX. Enfim, enfatizo a complexidade das questões presentes no dossiê São Paulo, hoje, somente inteligíveis em um enquadramento pluridisciplinar e que justifica a diversa formação profissional dos autores, o que por sua vez, remete para a base interdisciplinar e, mesmo transdisciplinar do campo do urbanismo e do planejamento urbano e regional.

O que nós historiadores poderíamos retirar desses comentários como subsídios para nossas pesquisas sobre o urbano? Como contribuir a partir de um enfoque

\footnotetext{
${ }^{8}$ Luiz de Anhaia Mello, formado na Escola Politécnica de São Paulo em 1913, foi ferrenho defensor de inclusão de áreas verdes no tecido urbano, fossem na forma de cinturão verde e a polinucleação como meio de, na época, deter o crescimento da capital paulista, ou no modelo de super-quadras dotadas de infraestrutura ajardinadas para o lazer ativo, e de áreas verdes dotadas de equipamentos a serem implantadas em bairros operários para o "recreio ativo" (1928, 1929, 1933, 1945). Francisco Prestes Maia, também formado pela Escola Politécnica de São Paulo em 1917, seguiu a orientação de plano radio-concêntrico proposto por Victor da Silva Freire, professor dessa Escola e responsável pela área de obras públicas do município de São Paulo entre 1899 e 1925. Autor de Estudo de um Plano de Avenidas para a Cidade de São Paulo (1930), O Zoneamento Urbano (1936), São Paulo, Metrópole do Século XX (1942), Os melhoramentos de São Paulo (1945) e vários artigos. Foi funcionário do Departamento de Obras Públicas, Prefeito da capital paulista durante o Estado Novo e entre 1961-1965.
} 
historiográfico e a avaliação dos conceitos utilizados pelo saber especializado? Enfim, como entrar no debate de uma questão essencialmente inscrita em um campo interdisciplinar/transdisciplinar?

\section{Interdisciplinaridade e Transdisciplinaridade}

$\mathrm{Na}$ intenção de sugerir a possibilidade de adentrar um campo de conhecimento de estrutura transdisciplinar sublinho, pois, a necessária aproximação interdisciplinar nos estudos das cidades. A transdisciplinaridade constitutiva do campo do urbanismo pode ser apreendida em seus inícios plurais, pelo menos desde o século XIX, inscritos em diversas áreas de conhecimento e nos diálogos, diretos e indiretos, entre especialistas de várias áreas e diversos países, o que também lhe confere caráter internacional e ambição universal na aplicação de tipologia e de modelos. Exige, ainda hoje, que pesquisadores de diversas áreas disciplinares mantenham o diálogo constitutivo desse campo.

Podemos acompanhar a trilha de pesquisadores que sinalizaram esses começos plurais mais amplos e complexos do que a mera relação entre industrialização, crescimento demográfico e inchaço urbano, que indicaram as vagas epidêmicas de alto poder mortal que varreram vários países europeus, a partir dos anos 1830, como ponto de saturação dos problemas das cidades e a formulação da "questão urbana", no decorrer da primeira metade do século XIX (Beguin, 1991). No equacionamento dos problemas e, em particular, nas propostas de solução formuladas por médicos, engenheiros, por filantropos e pelo poder público há, de modo explícito ou implícito, a adesão à concepção filosófica utilitária formulada por Jeremy Bentham. Seus Escritos sobre o Panótico ${ }^{9}$ (1787) dariam respostas a problematização da cidade a partir de,

\footnotetext{
${ }^{9}$ Em seus The Panopticon Writings, apresentados por Jeremy Bentham como cartas enviadas da Rússia no ano de 1787 , o autor propõe o Panopticon or The Inspection-House. Idea of a new principle of construction applicable to PenitentiaryHouses, Prisons, Houses of Industry, Work-Houses, Poor-Houses, Manufactures, Mad-Houses, Lazarettos, Hospitals and Schools. Foram editadas em Londres/Nova York: Verso, 1995, com edição e introdução de Miran Bozovic. A proposta de que se poderia obter poder sobre as mentes das pessoas por meio de "uma simples ideia em arquitetura" desdobrou-se na configuração das casas, em geral, e em especial nas casas destinadas à população operária com vistas a disciplinar seu comportamento considerado promíscuo e incompatível com o trabalho industrial. A filósofa e analista crítica das teorias urbanísticas Françoise Choay expõe com grande clareza o erro da maioria dos intérpretes ter atribuído a Bentham somente a autoria do projeto disciplinar pan-ótico, e deixar de lado ser ele o pai do utilitarismo, uma filosofia moral comparável a um projeto político (Choay, 1985, p. 257). Remeto também para As maquinaria inglesas do conforto do também filósofo François Beguin em vista do detalhamento das concepções utilitárias na implantação dos equipamentos de infraestrutura urbana e na organização disciplinar das casas, em particular, as destinadas à população trabalhadora (Beguin, 1991, p. 39-54).
} 
pelo menos, três pontos de vista: médico-higienista, engenharia-sanitarista e moralfilantrópico.

O modelo proposto para edificações destinadas a acolher grande número de pessoas - prisões, escolas, casernas, hospitais - estruturou, em sua aplicação mais ampla no tecido urbano, uma tipologia ${ }^{10}$ constituindo um complexo campo de observação e intervenção disciplinar: sanitário, arquitetônico e viário, de alto poder simbólico. A partir dele, configuraram-se ações destinadas a abrir o tecido tortuoso da antiga malha urbana medieval das cidades europeias, a desfazer a alta densidade da área edificada, a desamontoar pessoas e evitar comportamentos promíscuos, sanear casas e edifícios de uso coletivo, criar espaços verdes, embelezar espaços públicos, possibilitar a circulação intramuros viabilizando o fluxo de mercadorias e pessoas, fazer, enfim, com que o fluxo urbano coincidisse com o movimento do capital. Ações das quais dependiam a saúde, a formação moralizante e a possibilidade de modificar usos e costumes da população e, não menos importante, evitar ou conter revoltas sociais. ${ }^{11}$

A tipologia coparticipa do percurso formativo do urbanismo nos oitocentos, ao qual Piccinato atribui ser filho da arquitetura, herdeiro das Beaux Arts, e por isso conceder forte ênfase ao desenho na composição de planos para a intervenção nas cidades. Seriam planos reguladores operativos, pragmáticos, desenhados, que resumiam a "ideia de cidade". Planos que compuseram modelos de organização para a rede viária e de infraestrutura dos equipamentos urbanos, além de estipularem regras para a distribuição e tipologia construtiva, englobando o sistema de áreas verdes. Embora os planos urbanísticos do século XIX fossem sistematizados como técnica operativa, quando aplicados se mostraram inadequados em sua função de controlar, guiar e gerir as atividades urbanas, em boa parte, por seu caráter autoritário em franca oposição ao ideário liberal prevalecente na época. Pelas formas pouco definidas e algo ingênuas, a ação urbanística do século XIX mereceu pouco crédito, levando mesmo a afirmar-se sua inexistência como doutrina no período em que se estrutura a cidade moderna (Piccinato, 1974, p. 16-19, 72). O componente totalizador dos planos de

\footnotetext{
${ }^{10}$ Christine Boyer introduz a concepção contemporânea de "tipos" desenvolvida pela Escola de Arquitetura de Veneza desde meados do século XX. Segundo ela, Aldo Rossi definiu o conceito de "tipo" como "algo permanente e complexo, um princípio lógico anterior à forma e dela constitutiva". Assim, em cada "tipo" reside uma regra lógica ou um princípio estrutural explícito para os sentidos e a razão, encontrável na análise de cada objeto arquitetônico (Boyer, 1966, p. 178184).

${ }^{11}$ Além dos textos de Foucault e de vários adeptos das noções por ele desenvolvidas em relação à sociedade disciplinar, remeto para o instigante e já citado trabalho de Boyer, em especial o capítulo 2: City Images and Representational Forms.
} 
intervenção e de expansão urbana se expressou na evidente ambição de dar conta do complexo conjunto dos componentes físicos da cidade - casas, ruas, praças, canais, ferrovias, parques e jardins, edifícios públicos e indústrias - de definir e delimitar sua distribuição sobre o território. Componentes que obedecem a questões de ordem técnica formal, submetidas, entretanto, a interesses de investidores privados e a entidades públicas envolvidas em intervenções urbanísticas de uso coletivo. Para evitar a interferência mútua, os planos desenham e delimitam a transposição no território das áreas da competência do privado e do público (Calabi, 2000, p.37-38). Se as estratégicas e técnicas da higiene física e da higiene social e moral moldadas no século XIX agiram de modo combinado em suas tarefas de rasgar e abrir o tecido urbano denso e de definir a regulamentação edilícia, seus objetivos complementaram-se com a tarefa de formar o cidadão disciplinado. ${ }^{12}$

Seria somente na segunda metade do século XIX, quando se tornaram prementes as transformações e a expansão física das cidades, que estudos dedicados às intervenções urbanas começaram a ser publicados (Calabi, 2000, p. 38). A trajetória de formação do campo de reflexão e atuação sobre as cidades contou com a participação intensa e predominante de arquitetos e engenheiros - Ilefonso Cerdà, Reinhard Baumeister, Josef Stübben, Corneluis Gurlitt, Rud Eberstadt, Camillo Sitte, Otto Wagner, Donat-Alfred Agache, Eugène Hénard, Frederick Law Olmested senior e junior, Daniel Burnham e Edward Bennett, Le Corbusier, entre outros. Sua formação se torna mais complexa, quando consideramos a significativa presença de profissionais de áreas tão diferentes como, advocacia - Georges-Eugène Haussmann, estenografia - Ebenezer Howard; biologia - Patrick Geddes; ciência política - Hegemann; arquivo-paleografiahistória - Marcel Poëte, medicina - Jules Rochard, para citarmos só alguns dos diretamente envolvidos em planos (Welter, 2002; Piccinato e Calabi, 1974; Calabi, 2000; Collins, 2005), aos quais deveríamos somar juristas, filantropos, romancistas, jornalistas e intelectuais de diversas áreas que com escritos e programas assistenciais tiveram participação ativa na formulação da questão urbana (Topalov, 1999; Bresciani, 1982, 2009). A complexidade se amplia ao se considerar as diversas proveniências desses profissionais - britânicos, alemães, franceses, austríacos, espanhóis, italianos,

\footnotetext{
12 Donatella Calabi apresenta o levantamento de congressos, exposições e publicações no período formativo da disciplina urbanismo no Apêndice de Piccinato, 1974, p. 543-631. Christiane Crasemann Collins detalha as várias formas de diálogo e trocas de experiências entre profissionais da área de intervenções urbanas no final do século XIX e décadas iniciais do século XX em Collins, 2005.
} 
estadunidenses ${ }^{-13}$ que, uns mais, outros menos, circularam em viagens de estudos e usufruíram do conhecimento in loco de experiências de intervenções, projetos, planos. Tiveram a oportunidade de avaliar aplicações pontuais de planos para bairros, vilas e habitações operárias ou de população de baixa renda, bem como dos grandes planos de remodelação das cidades; participaram de exposições nacionais e internacionais, congressos especializados de diversos âmbitos, com trocas de informações e publicaram em textos o registro de suas experiências. Nessa trajetória formativa, o campo de atuação das intervenções urbanas assumia a denominação urbanismo no início do século XX. Sua dimensão internacional lhe permitiu consolidar a pretensão teórica à universalidade.

Contudo, a trajetória formativa do campo do urbanismo acumulou subsídios desde a primeira metade do século XIX, período em que as cidades, como Londres, Paris, Viena, Berlim, Barcelona, dentre outras, foram objeto de intervenções motivadas essencialmente por graves problemas sanitários e viários em suas múltiplas facetas, interligados ao crescimento demográfico e à industrialização. O médico Jules Rochard expunha, em texto introdutório à Encyclopédie d'Hygiène et de Médicine Publique, sob sua coordenação, que para levar "os povos modernos a aplicarem os princípios da higiene pública" fora necessário "o rude aguilhão de uma nova peste, a cólera" em seu trajeto letal pela Europa em 1832. Na Inglaterra, em 1838, Lord John Russell propôs que se fizesse uma pesquisa sobre "as condições sanitárias da população trabalhadora", entregue a coordenação ao advogado e jurista Edwin Chadwick, também responsável pela revisão das Poor Laws. ${ }^{14}$ Vários documentos do parlamento inglês deram sequência a essa pesquisa e expuseram entre 1840 e 1848 a precária situação sanitária de grandes áreas urbanas. As conclusões apontavam para a mortalidade urbana ser proporcional à densidade da população, mas que, além disso, o número da mortalidade dependia da areação e dos meios de eliminar a sujeira do ambiente. Tratava-se felizmente, conclui Rochard, de elementos malsãos [nuisances] evitáveis. Evitáveis, porém de difícil execução, não só em vista de questões técnicas, mas, principalmente, pelas resistências

\footnotetext{
${ }^{13}$ Não incluímos os vários arquitetos e engenheiros brasileiros ou atuantes no Brasil por simples questão de espaço. $\mathrm{O}$ texto que já se alongou bastante e merecerá outros trabalhos de modo a colocar no debate vários engenheiros dos quais, alguns especializados em sanitarismo, como Saturnino de Brito e Teodoro Sampaio, arquitetos e engenheiros arquitetos, como Victor da Silva Freire, Francisco Prestes Maia, Luiz Ignácio de Anhaia Mello, Alexandre Albuquerque, para ficar somente entre os vários que atuaram em São Paulo entre finais do século XIX na primeira metade do século XIX.

${ }^{14}$ Remeto para As maquinarias do conforto de François Beguin (1991), já citado, e para o capítulo VI intitulado, "The New Poor Law: pauper versus poor, do livro de Gertrude Himmelfarb, The Idea of Poverty (1985, pp. 147-176).
} 
às intervenções. Opunham-se aos higienistas os proprietários protegidos pelos juristas, o clero como guardião das tradições e mesmo a população pobre habituada a viver em cortiços e na rua. (Rochard, 1891, p. 21-23).

O autor relata que coube ao governo inglês não se deixar tolher pelas resistências e promulgar várias leis em 1847 e 1848 que tornaram obrigatório despejar os dejetos no esgoto. Em 1854, Londres teria suprimido 30.000 fossas fixas. Entretanto, os esgotos defeituosos derramavam-se no Tamisa e tornavam a situação de tal forma insuportável, que o Parlamento interrompia suas sessões devido ao intenso mau cheiro. A concepção de interceptores e coletores paralelos à área ribeirinha ao Tâmisa, somada aos reservatórios, permitiu afastar o esgoto e despejá-lo no mar; "um erro de princípio", diz Rochard. A despeito dessas tentativas mais ou menos bem sucedidas, o médico avalia que "em suma, a segunda metade deste século (XIX) foi marcada pelo enérgico remanejamento sanitário das cidades e de seu subsolo". E conclui: "Elas perderam em pitoresco, mas ganharam, como é correto e inevitável, em beleza real, se beleza implica antes de tudo em limpeza". O sistema de esgotos interceptores de Londres seria aplicado a Paris e Berlim adotaria um sistema radial; na sequência, várias outras cidades seguiriam os mesmos procedimentos (Rochard, 1891, p. 23-24).

Embora a Inglaterra seja sempre mencionada como pioneira em iniciativas no âmbito das leis e das práticas de intervenções urbanas, foram outras as cidades nas quais se desenvolveram amplos trabalhos resultantes de projetos de grande porte, planejados e implantados no decorrer da segunda metade do século XIX. Os planos para as cidades de Paris, Viena e Barcelona mantêm ainda o procedimento de desenhar as intervenções previstas sobre o mapeamento do complexo tecido urbano e podem ser considerados paradigmas da remodelação e expansão das cidades antigas. ${ }^{15}$ Constituem leituras diferenciadas da cidade com base nos problemas a serem enfrentados, mas em todos se encontram o levantamento das condições topográficas, as propostas e as finalidades almejadas. Não foram as únicas cidades a sofrerem intervenções na segunda metade do século XIX, mas seus planos, as condições sob as quais foram concebidos e aplicados, e os resultados obtidos oferecem subsídios para

\footnotetext{
15 O procedimento de desenhar, segundo Starobinski, obedecia, ainda no século XVIII a fazer da cidade uma imagem como parte do sistema da "retórica da persuasão" (Wieczorek, 1982, p.18), e se manteria, no detalhamento das ações a serem executadas sobre a superfície [ruas, avenidas, praças, parques, centros cívicos, arquitetura de prédios públicos, vias para o sistema de transportes coletivos] e no subsolo urbano, no início do século XX. Constituem casos exemplares o Plano of Chicago de Daniel Burnhan e Edward Bennett, de 1909 e o Plano de Avenidas para São Paulo de Francisco Prestes Maia, de 1930.
} 
entendermos o campo de tensões e de conhecimentos agenciados nos debates formativos dessa área de atuação nas cidades e o modo como decisões políticas e interesses divergentes se interpuseram e definiram os traçados urbanos contemporâneos, vale dizer, o modo pelo qual, nós citadinos nelas convivemos.

O plano para Paris da segunda metade do século XIX ganhou notoriedade. A dimensão monumental e o cuidado estilístico das obras mereceram relatos, registros em várias linguagens, e se tornaram referência para planejadores das décadas iniciais do século XX. Não são poucos os analistas críticos que lhe atribuem a condição de campo de inspiração para planos de remodelação e expansão de várias outras cidades no mundo. Também, a relação entre a capital francesa e Georges-Eugène Haussmann se tornou indissociável do traçado da Paris intramuros. A capital austríaca chega a nossos dias com o desenho do amplo anel de ruas que envolve a área central antiga - a Ringstrasse - pontuado pela sequência de prédios monumentais em estilos referidos a momentos da história, nela construídos. O plano de expansão de Barcelona, de Ildefonso Cerdà, fez da cidade um campo de intervenções e ocupação do território a partir de concepções estéticas e funcionais e, as modificações posteriores não desfizeram a grelha constitutiva do plano original. A cidade somente sofreria nova e notável intervenção por ocasião das Olimpíadas de 1992 já que as iniciativas da arquitetura moderna do GATEPAC (Grupo de Arquitectos y Técnicos Españoles para el Progreso de la Arquitectura Contemporánea) nos anos entre 1928 e 1939 foram abortadas pelo golpe e ditadura franquista (Pizza-Rovira, 2006).

\section{Paris-Haussmann}

Paris est et restera haussmannien car Paris sans le Paris d'Haussmann ne sarait plus Paris (Cars-Pinon,1991, p. 343).

Durante cerca de um século a persona de Haussmann e sua permanência na prefeitura do Sena, entre junho de 1853 e janeiro de 1870, estiveram negativamente ligadas a Luis Napoleão III e a Paris imperial, parceria interrompida pela derrota da França na guerra com a Prússia. Recentemente, quando do bicentenário da Revolução de 1789 e do centenário da morte do barão Haussmann, ele e sua obra foram redimidos e reavaliados por arquitetos, urbanistas, juristas, historiadores da arte e da literatura, como afirmam os autores do livro PARIS - Haussmann (Jean des Cars e Pierre Pinon, 
Picard, 1991). O peso dessa imagem negativa deixou marcas em escritos, desenhos, poemas, análises acadêmicas e críticas de intelectuais - lembro ensaios de Walter Benjamin, entre os quais, "Paris, capital do século XIX" e "Alguns temas em Baudelaire". Compõem registros que conjugam "os olhares dos contemporâneos de Haussmann [em] análises mais recentes que veem a Paris do 20 Império como um empreendimento especulativo, repressivo e esteticamente reacionário". (Cars-Pinon, 1991, p. 341-344)

Cars e Pinon advertem que a relação da cidade com Haussmann não deve obscurecer as ações dos prefeitos anteriores a ele em iniciativas para a abertura de ruas na densa e irregular malha central antiga e a intenção expressa por Luis Napoleão de abrir uma grande cruz de avenidas fincada no centro da cidade [Grande Croisée cardo romano], de estabelecer ligação entre as estações ferroviárias, bem como sanear e embelezar a capital. ${ }^{16}$ Napoleão esboçou o plano e Eugène Deschamps, responsável pelo Serviço do Plano de Paris, o traçou com precisão definindo as áreas a serem desapropriadas. Foi, porém, a vontade férrea de Haussmann apoiado por Napoleão III que possibilitou a transformação "dramática" da cidade ou sua "mise en scène monumental" (Cars-Pinon, 1991, p. 16-18).

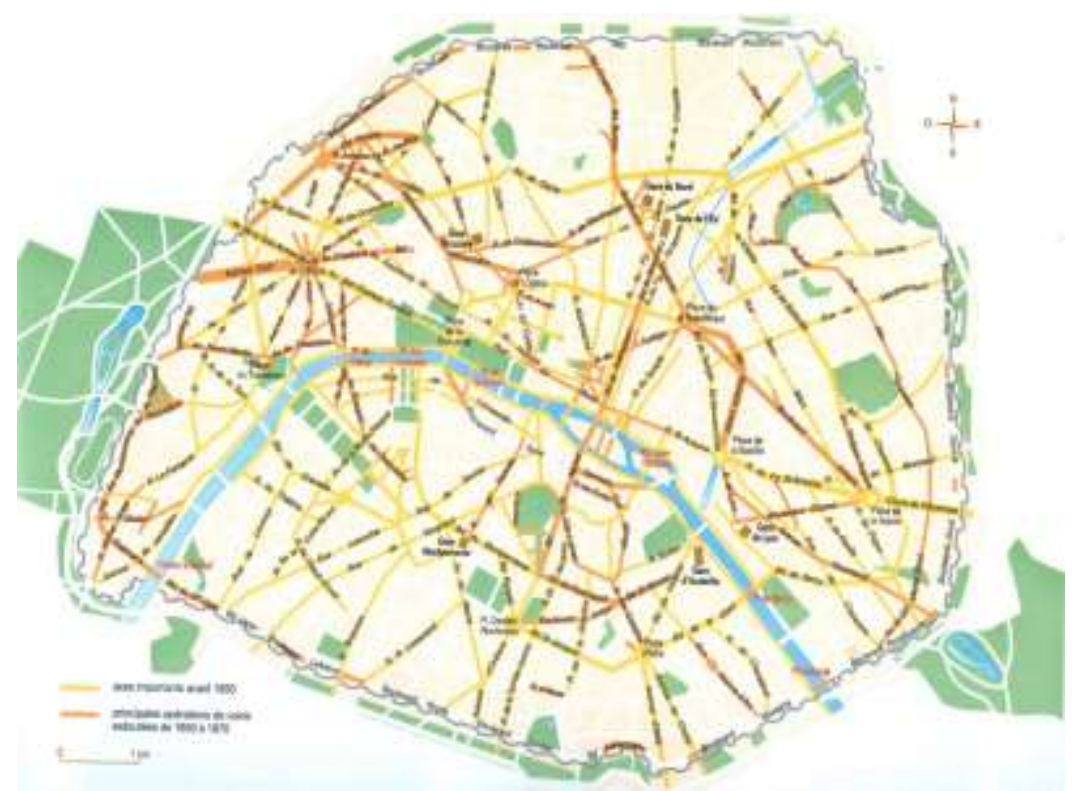

Figura 3: Plano geral das aberturas do período de Haussmann (a partir da obra da Commission d'extension de Paris, Considérations techniques préliminaires, prancha 6, Paris: Impr.Cahix, 1913): em amarelo - eixos importantes anteriores a 1850; em laranja - principais obras de infraestrutura executadas entre 1850 e 1870, período em que Haussmann ocupou o cargo de prefeito (Chadych e Leborgne, 1999, p. 155).

\footnotetext{
16 PINON, Pierre. Le double mythe Haussmann. In: IIIe CONGRÈS DE LA SOCIÉTÉ DES ÉTUDES ROMANTIQUES ET DIX-NEUVIÉMISTES: LA VIE PARISIENNE, 3., 2007, Paris, 2008. Disponível em: <http://etudes-romantiques.ishlyon.cnrs.fr/vieparisienne.html>. Acesso em: 20 ago. 2015. Agradeço a Carlos de Oliveira a indicação do artigo.
} v. 7, n. 10, jan /ago (2015). Dossiê História Urbana: a configuração de um campo conceitual 


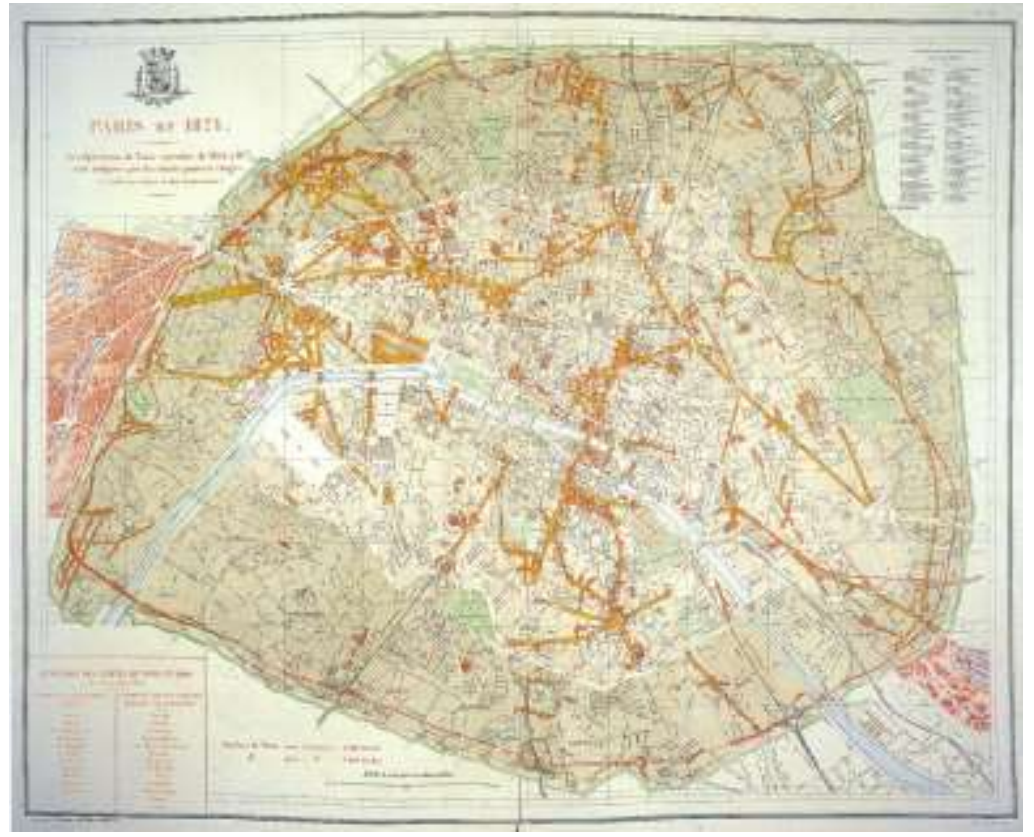

Figura 4: Paris em 1871. Aberturas rrealizadas entre 1854 e 1871. Atlas des travaux de Paris, 1889 ( Cars, 1991, p.92-93).

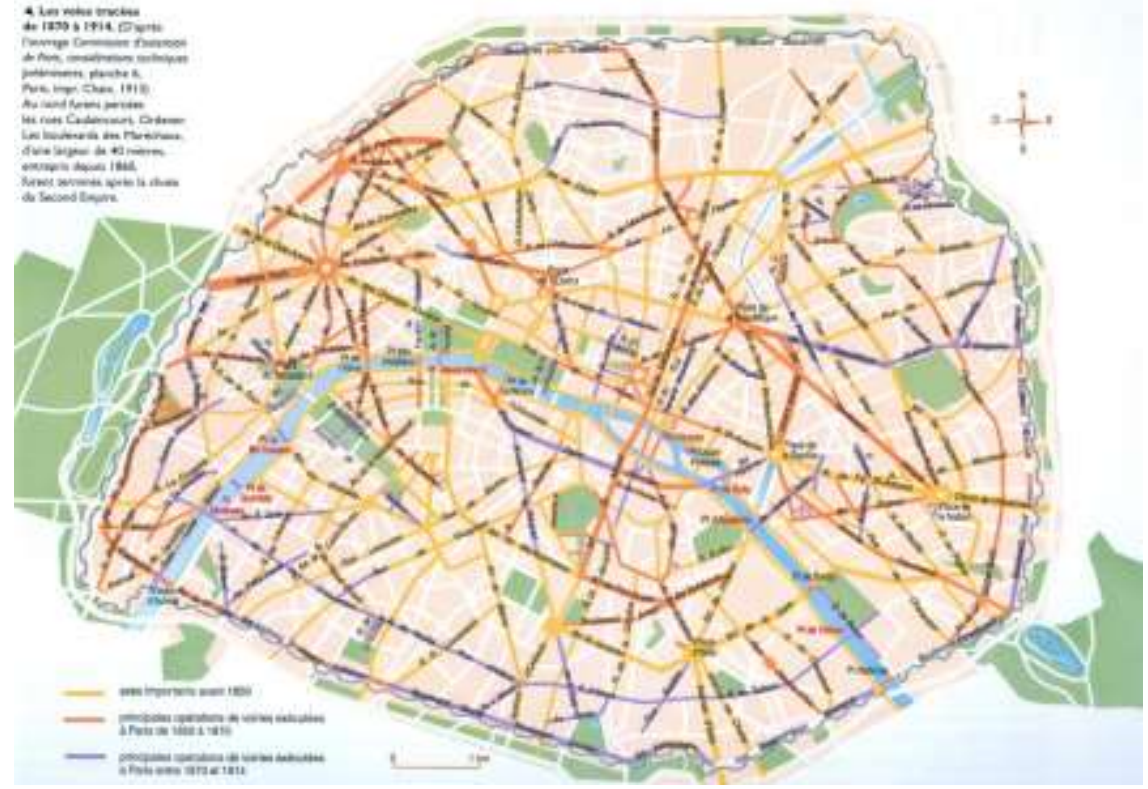

Figura 5: Vias traçadas entre 1870 e 1914. (a partir da obra Commission d'extension de Paris. Considérations techniques préliminaires, prancha 6, Paris: Impr. Chaix, 1913): em amarelo - eixos importantes anteriores a 1850; laranja - principais obras de infraestrutura executadas entre 1850 e 1870; lilás - principais obras de infraestrutura realizadas entre 1870 e 1914 (Chadych e Leborgne, 1999, p. 165). 
As transformações mais visíveis consistem nos trabalhos de abertura de vias, as percées (aberturas) ou o chamado éventrement du vieux Paris (abertura do ventre do antigo Paris) e são consideradas o primeiro exemplo de política urbana, concebida com a intenção de sanear, ampliar e embelezar a capital francesa, efetuada em três etapas. A partir de 1852, inicia-se a construção da "grande croisée" com o eixo norte-sul (boulevard Sébastopol, boulevard Saint-Michel) que exigiu a demolição de casas, de modo a reservar o centro antigo para edifícios administrativos e liberar o entorno de prédios simbólicos como a catedral de Notre Dame. A segunda e a terceira etapas, iniciadas em 1858 e 1860, respectivamente, visaram assegurar ligações entre os antigos bairros e os recentemente anexados. Nos grandes eixos de circulação Haussmann implantou edifícios públicos de arquitetura beaux-arts (a Ópera) e prédios de uso coletivo (mercados, casernas, escolas, hospitais, prisões), remanejou bosques (Boulogne, Vincennes) e criou jardins públicos. Também realizou grandes obras para a instalação de equipamento de saneamento (distribuição de água e esgotos) e reorganizou, com menos sucesso, os transportes coletivos. Essas intervenções podem ser sintetizadas em três sistemas: a rede de bulevares anulares, vias radiais e diagonais perpendiculares, a rede de esgotos e canalizações, e a aeração por meio de bosques, parques e arborização de avenidas, que organizadas em subsistemas estruturam um esquema hierarquizado de infraestruturas. (Oblet, 2005, p. 24-25, Wieczoreck, 1981, p. 76). A noção urbanística preponderante na remodelação de Paris se expressa no desenho clássico barroco - grandes vias cujo ponto de fuga se via coroado por um monumento ou uma edificação monumental, com as laterais normatizadas em termos de alinhamento e de fachadas compondo um décor teatral e praças em estrela implantadas em pontos estratégicos da malha urbana ${ }^{17}$ (Cars-Pinon,1999, p. 345-352).

\footnotetext{
${ }^{17}$ A Cartografia no final do livro apresenta 7 mapas, concebidos por Pinon e realizados por Patrick Galas, e oferece excelentes imagens das intervenções e as respectivas datas de implantação (Cars-Pinon, 1999).
}

REVISTA ELETRONICA DO CENTRO INTERDISCIPLINAR DE ESTUDOS SOBRE A CIDADE . ISSN 1982-0569 v. 7, n. 10, jan /ago (2015). Dossiê História Urbana: a configuração de um campo conceitual 


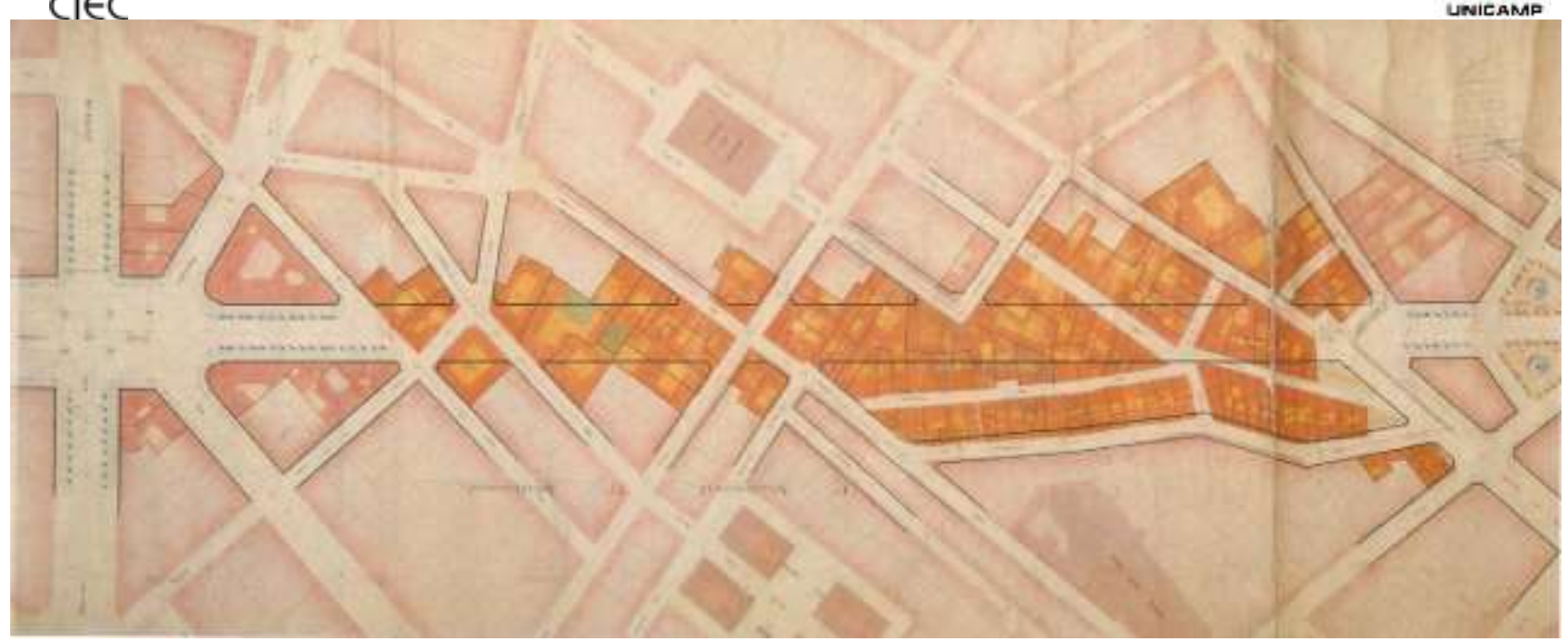

Figura 6: Plano para a abertura da avenida da Ópera traçado sobre o tecido urbano edificado, com destaque para os imóveis a serem desapropriados, anexado ao decreto de 27.6.1876. Documento do Service technique de la documentation foncière, Ville de Paris. Documento Pavillon de l'Arsenal (Beyler, 1992, p.45).

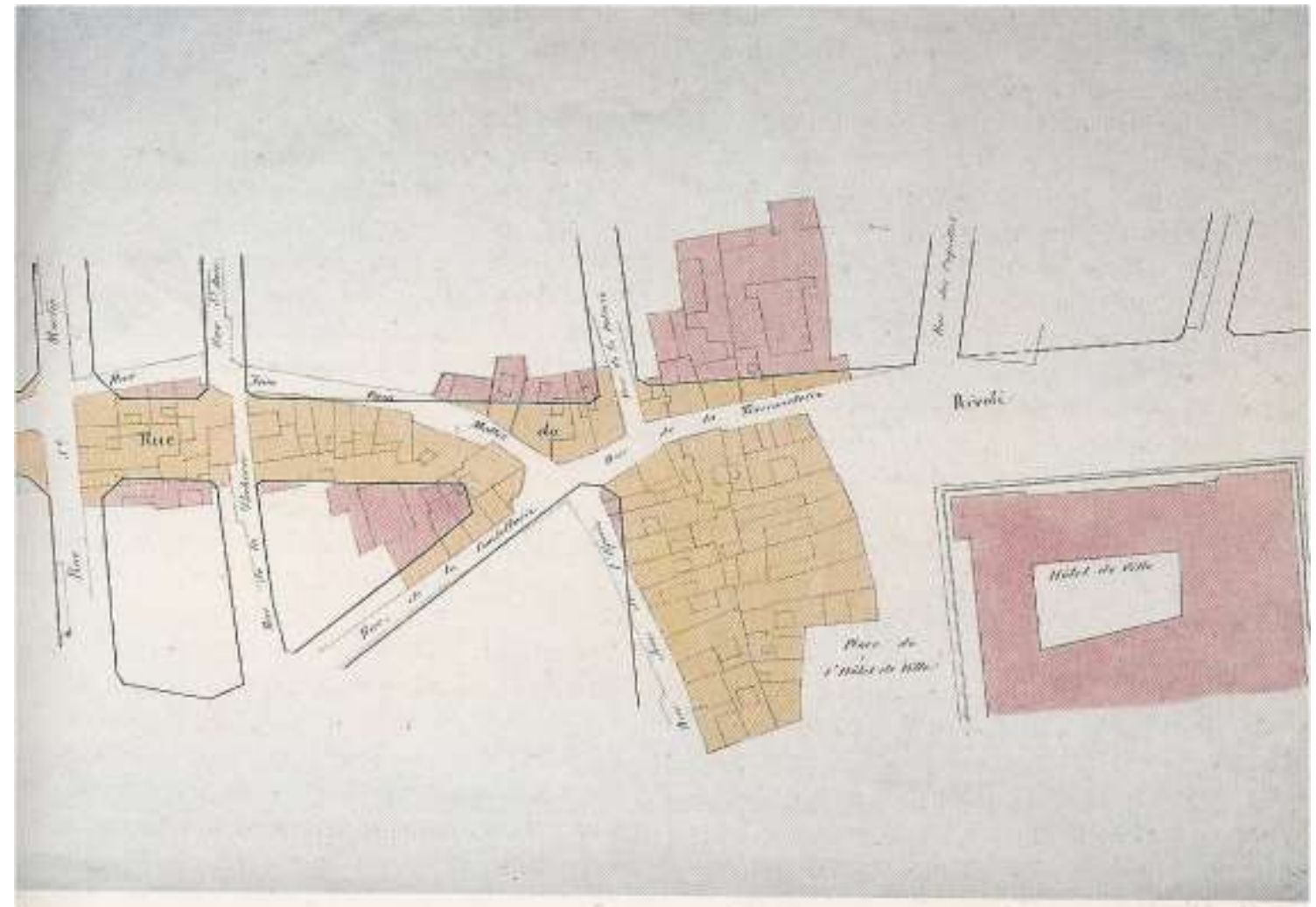

Etude du percement de la rue de Riupli entre la rue Saint-Martin et I'Hötel de Ville. Bibliothètque Histarigue de La Ville de Paris.

Figura 7: O traçado da abertura da rua de Rivoli sobre o tecido urbano edificado de Paris na área próxima à Prefeitura [Hôtel de Ville] de Paris (Cars e Pinon, 1991, p. 65). 
Numerosas análises caracterizaram como repressivas as intervenções do $2^{\circ}$ Império e justificam suas considerações em vista da lei de expropriação de 1852, que autorizava Haussmann a tomar decisões em nome da utilidade pública, sem consulta ao legislativo. À lei somou-se o gosto pelas grandes perspectivas e arquiteturas imponentes e a abertura de largas vias estratégicas que uniram a preocupação em facilitar a circulação e satisfazer diretrizes sanitárias e a intenção de impedir os movimentos revolucionários. O afastamento da população artesã e operária para a periferia de Paris completou a estratégia de intervenções. Afinal, os massacres de 1838 e a revolução de 1848 ainda faziam ouvir seus ecos. Por isso, diz Oblet, a comuna de 1871 foi vista como a reconquista do coração da cidade (Oblet, 2005, p. 26-28). O remanejamento da população trabalhadora empurrada para os bairros periféricos do norte em função da valorização da área reformada e da alta dos aluguéis, deu lugar na imprensa a denúncias sobre os milhões gastos "para fazer com que o ar penetrasse na velha Paris", enquanto, "se formavam nas extremidades da cidade grupos de casas estreitas e malsãs, nas quais uma especulação detestável amontoava os operários". (Cars-Pinon, 1991, p. 78)

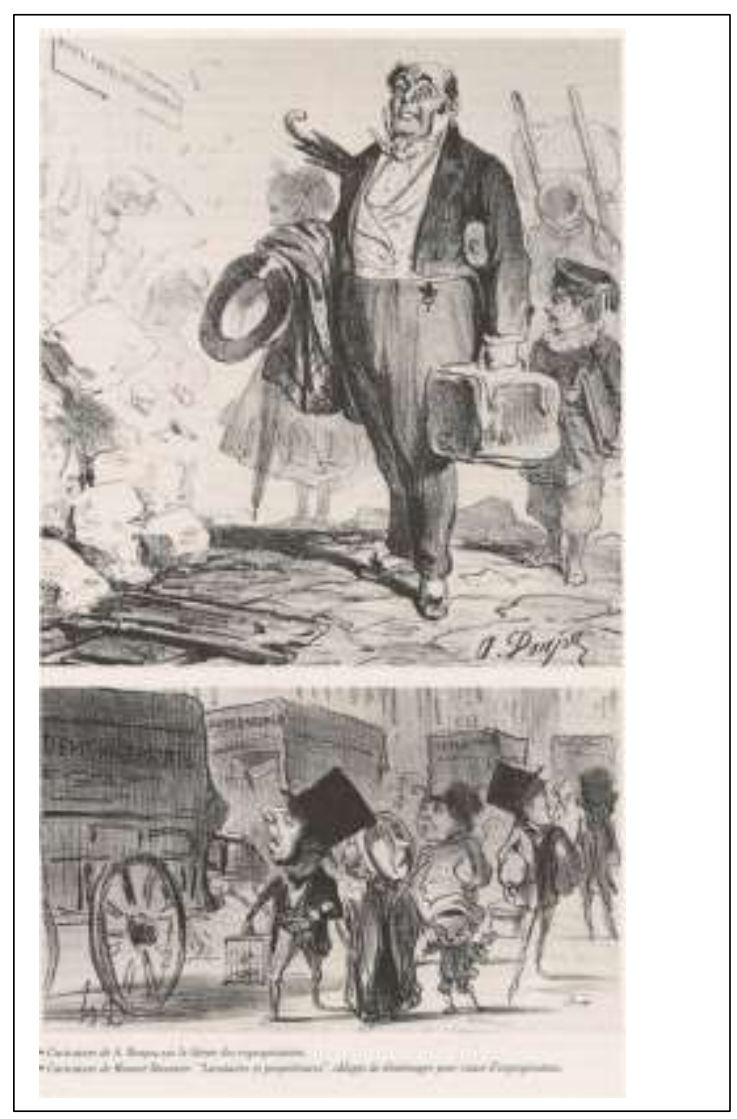

Figura 8: Caricatura de A. Darjou sobre o tema das expropriações e Caricatura de Honoré Daumier. Locataires et propriétaires, aqueles obrigados a se mudarem devido ás expropriações (Cars e Pinon, 1991, p. 75). 

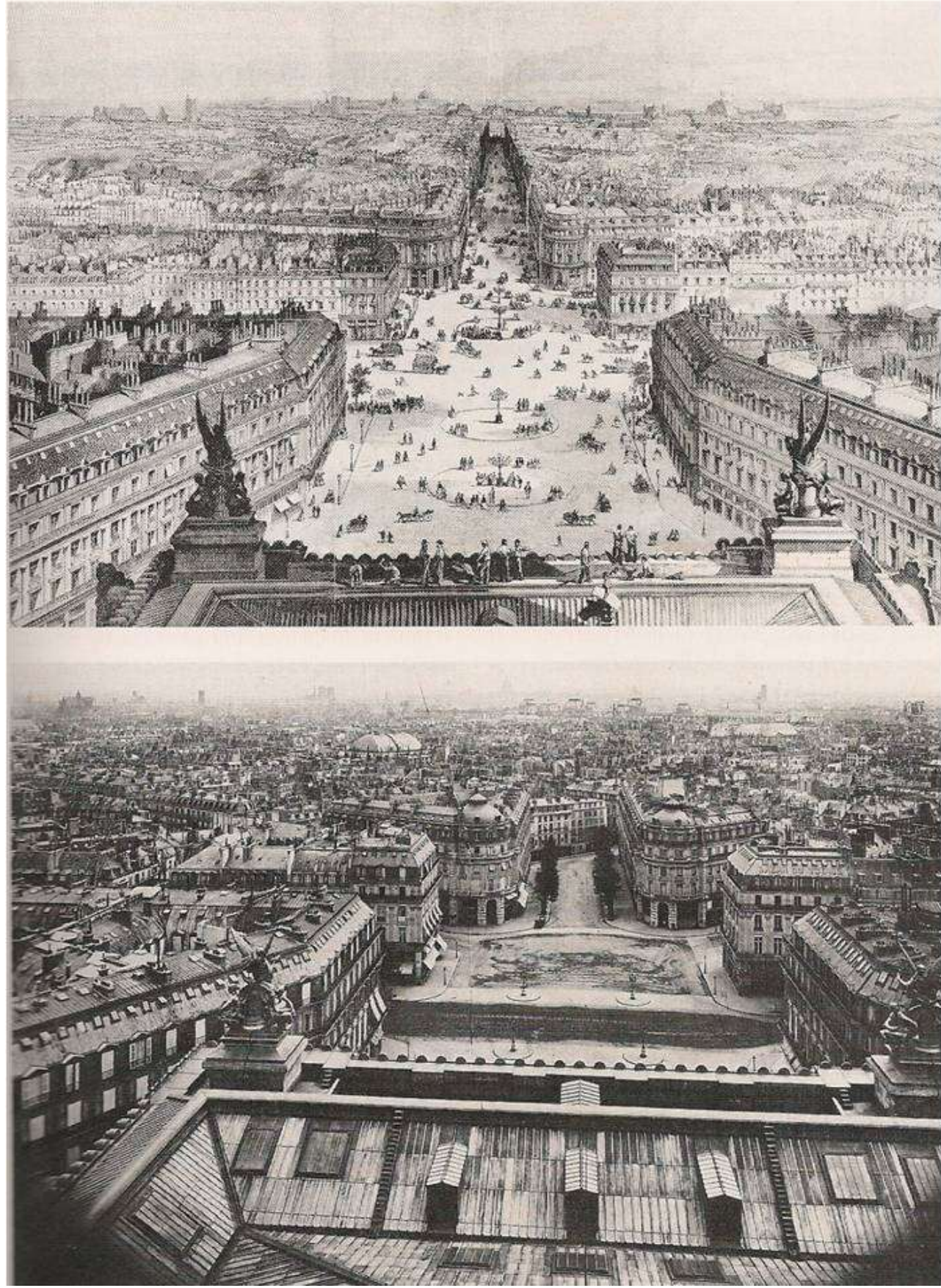

Figura 9: Projeção da avenida da Ópera completa em gravura de A. Deroy publicada no Le Monde Illustré de 27 de março de 1869; avenida da Opera inacabada vista da Ópera em fotografia de cerca de 1870 (Cars e Pinon, 1991, p.197). 
O autoritarismo na gestão das intervenções para a remodelação do tecido urbano não suspendeu a base liberal da política que deixava ao sabor do mercado e mesmo abandonava a questão da habitação operária. Do ponto de vista de Haussmann, não seria economicamente racional construir casas baratas para os operários que, frente os altos preços dos alugueis e na pouca disponibilidade de moradias se viram deslocados para os subúrbios. Embora não fosse uma política deliberada, a "haussmannização" da cidade deu lugar a formação de duas Paris: os ricos ao oeste e os pobres a leste. A segregação - oeste burguês rico-leste operário pobre - se mantém como linha divisória da cidade atual. Ainda em 1993 se concluía ser esse o maior problema da aglomeração parisiense, a despeito das iniciativas de defensores da "economia social", adeptos das teorias "solidaristas" e de setores "esclarecidos da burguesia". 18 Iniciativas de ampliação das possibilidades para o transporte coletivo de modo a abreviar os longos deslocamentos dos trabalhadores também tiveram poucos resultados. A intenção de construir o metrô foi tema de longo debate durante os últimos vinte anos do século XIX (Oublet, 2005, p. 32-37, 48-50). Somente no início do séc. $X X$ o arquiteto Eugène Hénard, se posicionaria frente ao aumento da circulação de automóveis quanto à necessidade de substituir as fortificações por um bulevar circular. Também só em 1911, sob a tutela do Museu Social, fundado em 1895, e com a colaboração de Donat-Alfred Agache e Henri Prost o primeiro plano para unificar Paris e os subúrbios mais próximos por meio de um dispositivo de vias e jardins (Cars-Pinon, 1991, p.332, Oublet, 2005, p. 39-41). Em 1925, Le Corbusier apresentava seu Plano Voisin e propunha, no livro Urbanismo, uma intervenção cirúrgica no centro de Paris invocando Haussmann - "esse homem temerário e corajoso" - como padrinho. (Cars-Pinon, 1991, p. 335)

\footnotetext{
${ }^{18}$ Marie-Claude Blais afirma ser no ano de 1896 que a ideia de solidariedade, já corrente no debate acadêmico, entra na política e se torna a doutrina oficial da "república social" na França por proporcionar fundamento à instável IIIa República saída da derrota frente à Prússia em 1870 e da dolorosa experiência da Comuna de Paris de 1871, submetida a uma longa depressão entre 1873 e 1895 e aos numerosos movimentos de trabalhadores. Com base em princípios da solidariedade cristã católica, deu continuidade às iniciativas da "economia social" dos anos de 1860, fundada por Ferdinand Le Play em sua preocupação com a população trabalhadora e suas condições de vida e trabalho, inspirou também a formação do Musée Social em 1895 (Blais, 2007; Horne, 2004; Chambelland, 1998; Chevalier, 1992; Hayward, 1956; 1961).
} 


\section{韫}

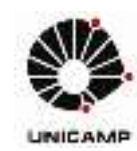

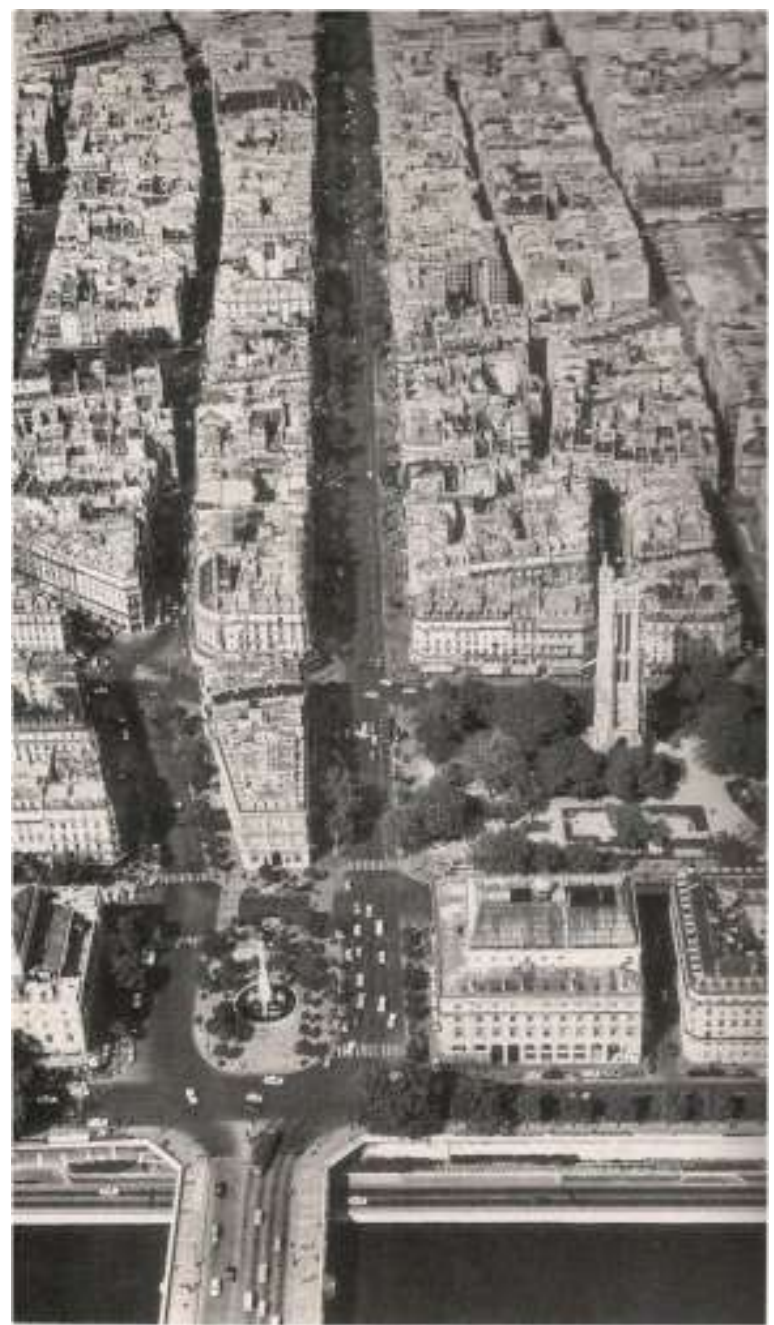

Figura 10: Resultado de aberturas de vias no tecido urbano já edificado da cidade de Paris. Vista aérea do bulevar Sébastopol, das praças Saint-Jacques e Châtelet (Cars e Pinon, 1991, p.70).

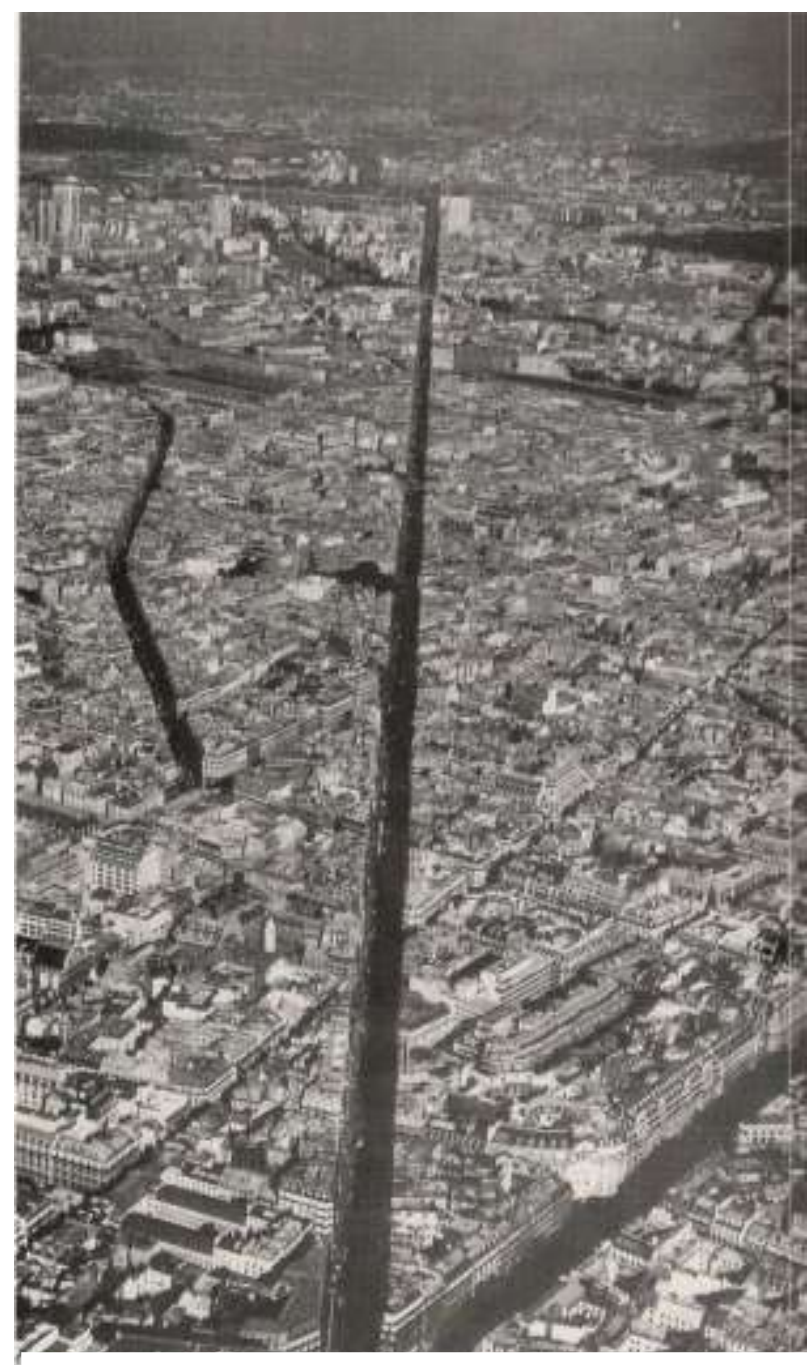

Figura 11: Resultado de aberturas de vias no tecido urbano já edificado da cidade de Paris. Vista aérea da rua Lafayette (Cars e Pinon, 1991, p. 248).

\section{Viena - Ringstrasse}

Quanto à qualidade dos planos urbanísticos, Calabi considera Viena uma cidade particularmente emblemática pelas respostas dadas com as intervenções da segunda metade do século XIX a dois problemas centrais do urbanismo: atendeu à necessidade de implantar uma rede ferroviária metropolitana como suporte para o desenvolvimento dos subúrbios e definiu o zoneamento como instrumento de projetos para a expansão da cidade (Calabi, 2000, p. 157). Carl E. Schorske privilegia outra dimensão do plano de intervenção: "o novo desenvolvimento de Viena, devido à sua concentração 
geográfica, superou, em impacto visual, qualquer reconstrução urbana do século XIX mesmo a de Paris". E prossegue: "O que dominou a Ringstrasse não foi a utilidade, mas a autoprojeção cultural dos anos 1860 - embelezamento da imagem da cidade". Merece dele ênfase especial "...o grande fórum construído ao longo da Ringstrasse de Viena, com seus monumentos e residências por oferecer um índice iconográfico da mentalidade do liberalismo austríaco ascendente" (Schorske, 1988, p. 45).

Tal como em Paris, também em Viena a situação política favorável abriu em meados do século XIX o debate sobre as necessárias intervenções na cidade ainda cercada por fortificações. A ascensão ao poder dos liberais e a introdução do governo constitucional na Áustria em 1860, estimulou a remodelação da capital, cuja linha de força definiu-se pela abertura de uma sequência de amplas ruas compondo a Ringstrasse que se converteu, diz Schorske, em um conceito - o Ringstrassenstil - a "invocação mental de uma época", equivalente à noção "vitoriano" para os ingleses ou "Segundo Império" para os franceses. Dá destaque à força de autorepresentação da Ringstrasse, como expressão de dois traços da alta cultura austríaca do século XX, implícita à teoria urbana e ao desenho espacial: a sensibilidade aos estados psíquicos e às consequências negativas da racionalidade como guia da vida.

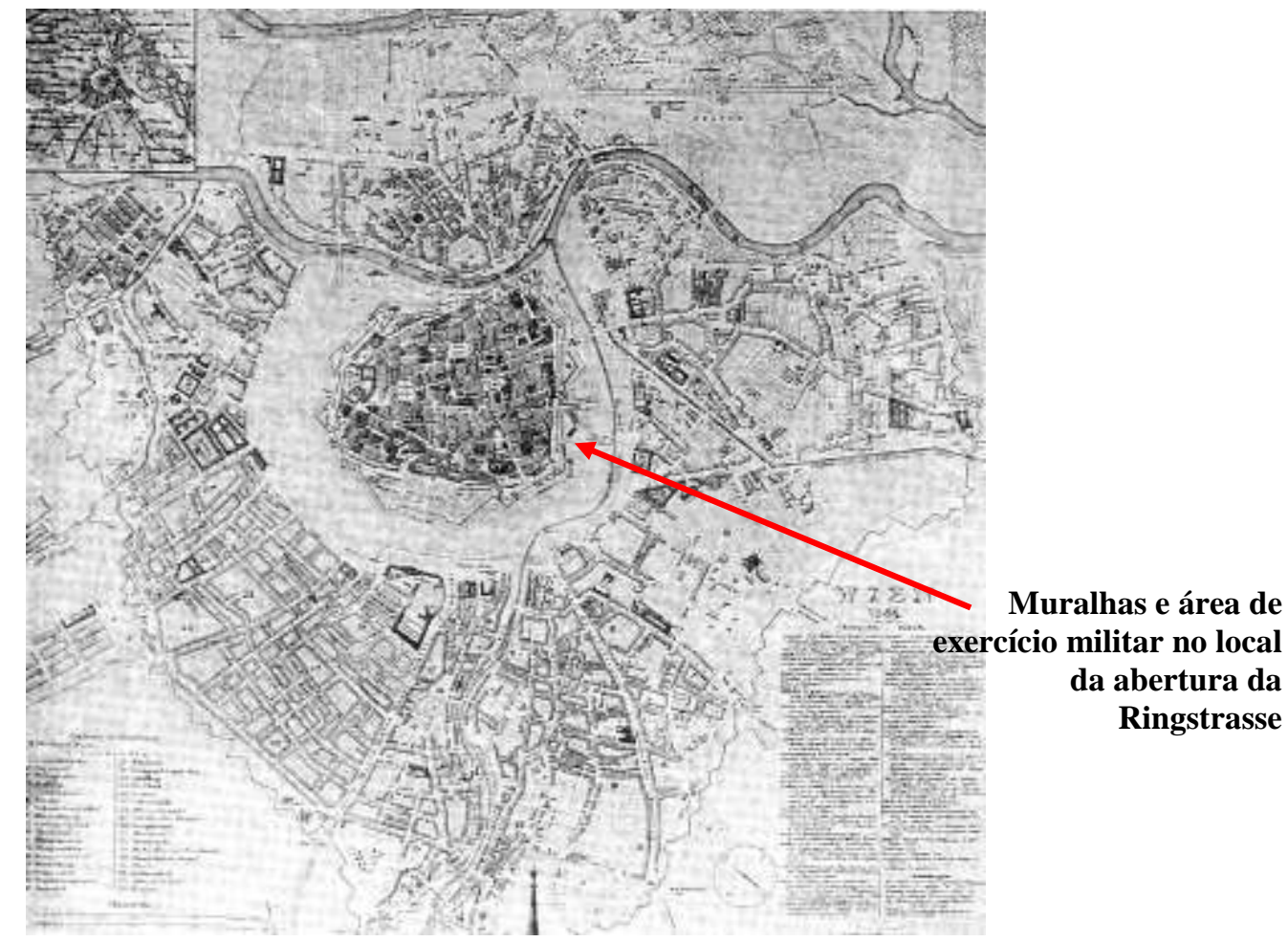

Figura 12: Viena em 1844, antes da reforma e reconfiguração (Schorske, 2000, p.145). 


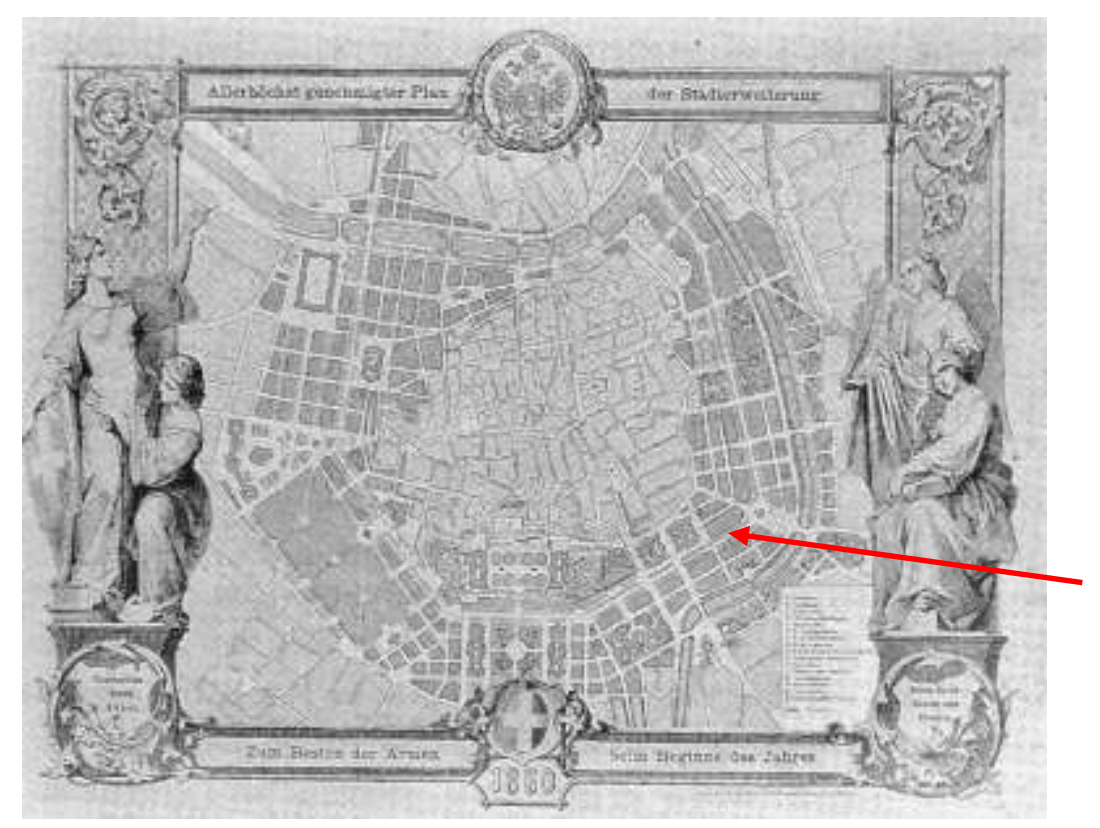

Projeto de urbanização da área adjacente à Ringstrasse

Figura 13: Publicação oficial do Plano para a implantação da Ringstrasse, 1860 (Schorske, 2000, p.153).

Sem dúvida a imagem imponente da composição viária se impõe pela dramaticidade do anel de ruas, em escala e estilo; seus projetistas inverteram o procedimento barroco de colocar um edifício no centro focal ao utilizarem o espaço horizontal da Ringstrasse como suporte dos edifícios destinados a abrigar os edifícios do governo constitucional e a alta cultura. O panfleto que, em 1860, apresentou os projetos dos novos edifícios públicos registrava iconograficamente a ideologia dos novos patrocinadores - a força da lei e a cidade embelezada pela arte (Recht und Kultur). Contudo, enfatiza o autor, embora o compromisso barroco se manifestasse na composição dos espaços abertos e das edificações, mereceu grande atenção a dimensão menos dramática das obras de canalização do Danúbio, no intuito de evitar as frequentes enchentes, a implantação do sistema de fornecimento de água e a construção do primeiro hospital da cidade (Schorske, 1988, p. 43-50).

O direito à autogestão municipal obtida pelos liberais em março de 1850 havia abolido a jurisdição política feudal e incorporado à cidade os subúrbios densamente urbanizados externos ao anel das fortificações. A derrubada da muralha e a ocupação civil da ampla esplanada de exercícios militares circundante enfrentavam a oposição dos militares enfraquecida, contudo, pelos ecos da revolução de 1848, quando o inimigo interno - "o proletariado dos subúrbios e locais distantes" e a "Legião Acadêmica composta por professores e estudantes da universidade e de outras instituições de 
ensino" -, obrigou o exército austríaco a uma retirada forçada, seguida das posteriores derrotas frente à França e ao Piemonte em 1859 e à Prússia em 1866. Concedeu-se, entretanto, ao exército a exigência da largura das ruas formadoras da Ring "projetada como uma artéria larga cercando totalmente a cidade interna a fim de facilitar o deslocamento de homens e materiais para qualquer ponto de perigo" (Schorske, 1988, p. 49,57$)$.

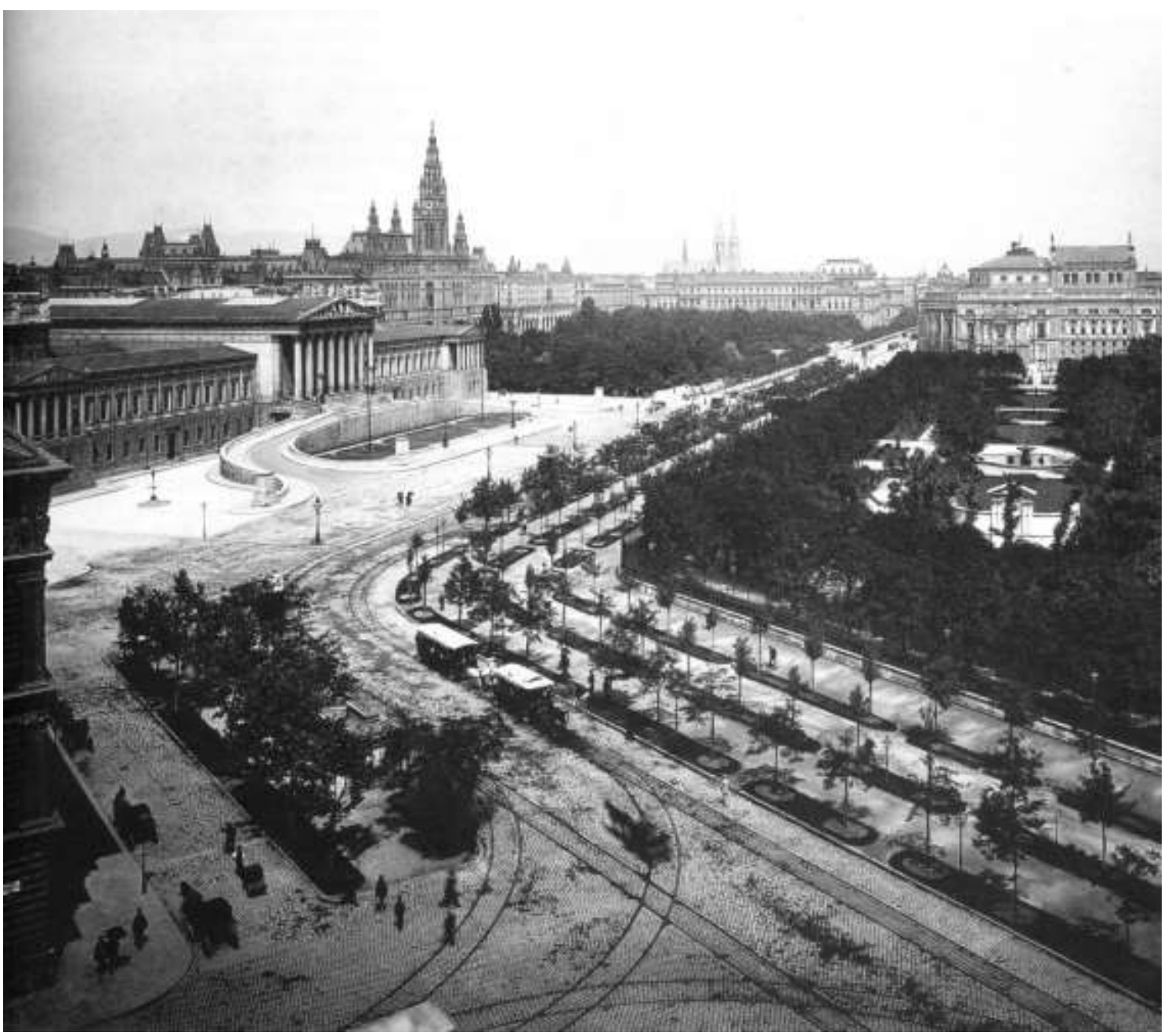

Figura 14: Viena Ringstrasse: à esquerda o Parlamento (1873); Prefeitura (1872-1873); ao fundo a Universidade (1873-1874); à direita Burgtheater (1874-1888) [LL. Viollet] (Beyler, 1992, p.51). 


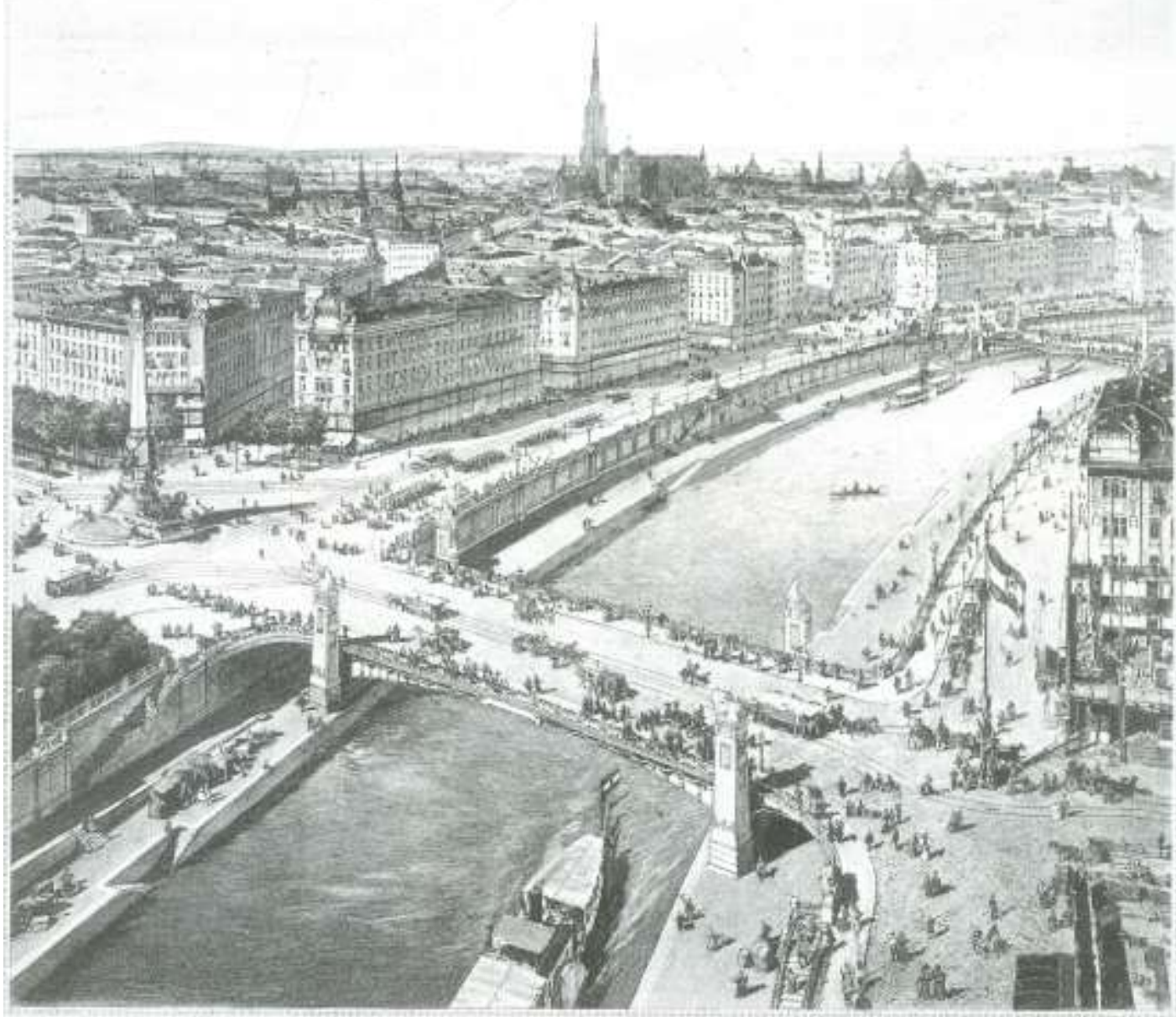

Figura 15: Vista do cais do canal do rio Danúbio retificado e da nova ponte (Wagner, 1987, p. 138).

O compromisso entre a reação militar e a concepção moderna viária mostraria resultado surpreendente. Na opinião de Schorske, "embora a escala e grandeza da Ring tenham surgido da força persistente do barroco, a concepção espacial que inspirou seu projeto era nova e original". Não se optou por unir o subúrbio à cidade por amplas perspectivas com monumentos centrais; o sistema radial rígido se viu interrompido pela Ring para o qual convergia a maioria das ruas sem atingirem a parte antiga da cidade. Localizados sem relação mútua, os edifícios representativos da burguesia tiveram na Ring seu único princípio de coesão. Sem um foco central, cada edifício manteve integridade e independência acrescidas pela ênfase teatral dos diferentes estilos arquitetônicos. Os projetos seguiram a opção historicizante de unir estilo à função: Rathaus (poder municipal) - gótica; o Burgtheater (Opera) - barroco inicial com o forro da escadaria pintado por Gustav Klint; a universidade - renascentista; o Reichsrat (Parlamento) - estilo grego clássico com estátuas ladeando a rampa de acesso, e que, 
por falta de heróis políticos do país, tomou-se de empréstimo ao Capitólio romano um par de domadores de cavalos e historiadores clássicos (Tucídides, Políbio) completada a sequência de esculturas da rampa com Palas Atena - protetora da Polis, como símbolo central e representativo da unidade liberal entre política e cultura racional. Apesar do caráter moderno do plano viário para a cidade, em termos arquitetônicos, diz Schorske, imperou "O primado do imponente estilístico sobre o útil funcional" (Schorske, 1988, p. 49-61).

As intervenções em Viena abriram acirrado debate entre dois arquitetos cujas posições divergentes formularam teorias definidoras de concepções urbanísticas. Camillo Sitte, envolvido em termos profissionais, mais com "artes e ofícios" e menos com arquitetura e planejamento, buscou argumentos na concepção comunitária de cidade ao criticar os amplos espaços vazios da Ringstrasse. Embora elogiasse a opção histórico-estética dos edifícios, discordou de suas dimensões monumentais e da disposição em meio a imensos espaços tal qual "um bolo numa travessa".

Em termos gerais, sua crítica recaia na forma pela qual os especialistas e técnicos, os engenheiros em particular, agiam como geômetras ao desenharem suas grelhas sobre os mapas desconsiderando a topografia do terreno. Não se opunha radicalmente à linha reta e ao traçado urbano em grelha sobre os mapas das cidades, pois os considerava inevitáveis em vista do acelerado crescimento urbano. Porém, a seu ver, o princípio geométrico não deveria se estender ao "emprego estereotipado das construções em blocos compactos e sólidos", sem a devida consideração à importância de se humanizar a monotonia e interrompê-la com praças públicas, ruas e pátios particulares. Sitte opunha-se à concepção moderna da engenharia de transito, em crítica direta aos engenheiros alemães - Baumeister e Stübben, que, além de autores de planos, publicaram livros e manuais (Baumeister, 1876; Stübben, 1907). Criticava a ênfase dada ao sistema viário característico do plano parisiense, no qual praças em estrela tinham como única função facilitar a circulação de veículos, e a ênfase complementar aos pressupostos da higiene e do sanitarismo (Collins, 2006, p. 35-37, 42-43). 


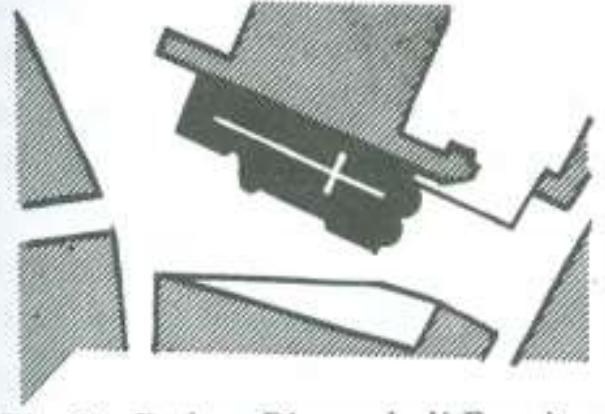

Fig. 30. Padua: Piazza degli Eremitani. [From Martin]

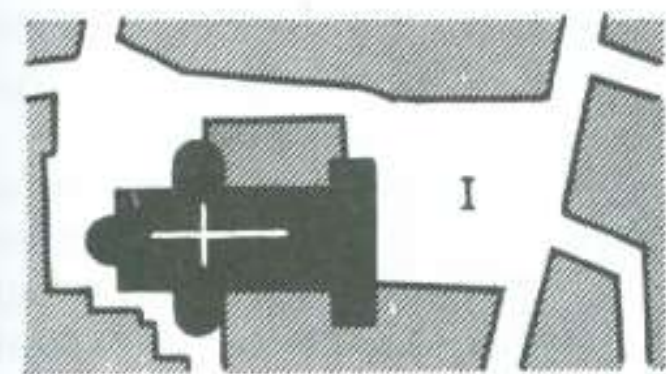

Fig. 32. Padua: Piazza del Duomo (I)

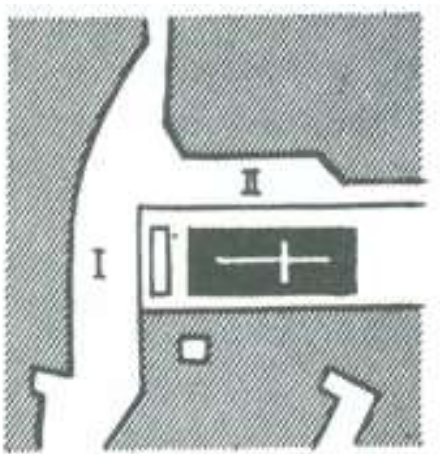

Fig. 31. Syracuse.

\section{Piazza del Duomo.-}

II. Piazza Minerva

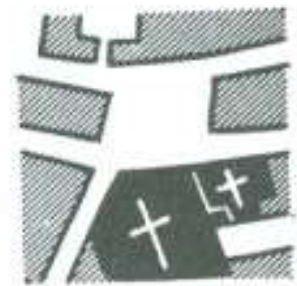

Fig. 33. Palermo:

Piazza S. Francesco

Figura 16: Exemplos de praças antigas irregulares em várias cidades: Padua, Siracusa, Padua e Palermo como apoio aos argumentos críticos de Camillo Sitte a respeito das avenidas de longuíssimo comprimento e absoluta regularidade das praças públicas (Sitte, 1986, p. 185).

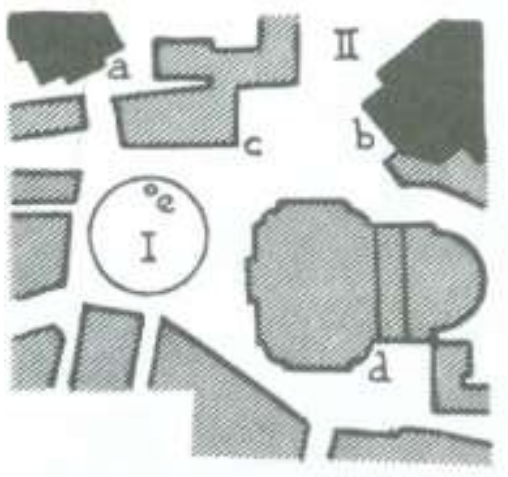

Fig. 71, Bremen. I. Marketplace. II. Cathedral square. -a. Frauenkirche. - b. Cathedral. - c. Rathaus. d. Bourse. - e. Roland statue. [From Martin]

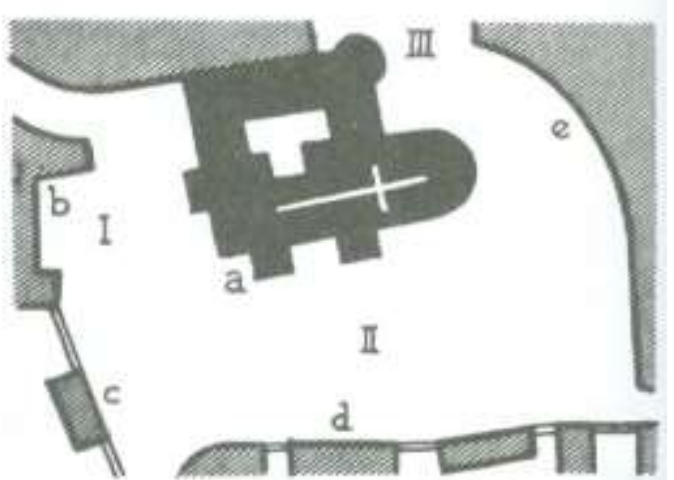

Fig. 72, Münster: Cathedral square. a. Cathedral. - b. Episcopal Residence. - c. Museum. -d. Government building. - C. Bank

Figuras 17 e 18: Exemplos de praças públicas em cidades do norte da Europa comparados às de cidades italianas: Bremen,Munique, Salsburgo como apoio aos argumentos de Camillo Sitte (1986, p. 214). 
Sua adesão a ideia de cidade como obra de arte, Sitte a expôs em $A$ construção da cidade segundo princípios artísticos, de 1889, propondo devolver ao urbano sua dimensão humana e redimi-lo do "nosso século matemático". Trazia em defesa de sua posição imagens nostálgicas do passado: enaltecia as formas livres da organização medieval do espaço urbano e as praças como lugar de encontro e sociabilidade e meio para libertar "o homem moderno da maldição da solidão urbana" (Schorske, 1988, p.8088). ${ }^{19} \mathrm{O}$ embate entre Sitte e os engenheiros alemães não impediu a Stübben de lamentar ter o arquiteto vienense perdido a batalha contra a o plano de abertura do centro antigo de Viena na década de 1890. De seu lado, Sitte não deixou de elogiar o aspecto funcional do projeto arquitetônico de Wagner para o Museu da Cidade de Viena, embora não tenha sido a proposta vencedora, criticando-o somente pela escolha do ferro e do vidro para o exterior, a seu ver, inadequados para a expectativa de um edifício de grande importância simbólica. A resistência de Sitte à arquitetura saída do movimento Secessão devia-se a sua preferência pela "grande arte da arquitetura monumental", pois para ele, o estilo Secessão seria mais adequado para as "artes menores" dos prédios para moradias e de seus espaços interiores (Collins, 2006, p. 1718).

$\mathrm{Na}$ contramão de Sitte, Otto Wagner, adepto de concepções radicalmente utilitárias e dos valores racionais e urbanos da sociedade moderna, criticou nas edificações da Ring o mascaramento da modernidade e de suas funções por trás de cortinas estilísticas da história. Sua adesão mais completa e a posição de teórico e estilista funcional viriam na década de 1890 quando do envolvimento com o projeto de engenharia ferroviária urbana e, em termos arquitetônicos, com o movimento de Secessão do Art Nouveau vienense. O debate entre as concepções de cidades dos dois profissionais prosseguiria anos a fio e, no século $X X$, manteve-se acesso na posição de Lewis Mumford e Jane Jacobs, "reformadores criativos" partidários da cidade comunitária, oposta a Pevsner e Giedion "seguidores fervorosos do funcionalismo moderno" (Schorscke, 1988, p. 44, 92-94).

\footnotetext{
${ }^{19} \mathrm{O}$ debate entre Camillo Sitte e Otto Wagner pode ser acompanhado em Schorske, 1988, p. 78-94, Calabi contribui também com a biografia de Otto Wagner (Calabi, 2000, p. 160-162).
} 


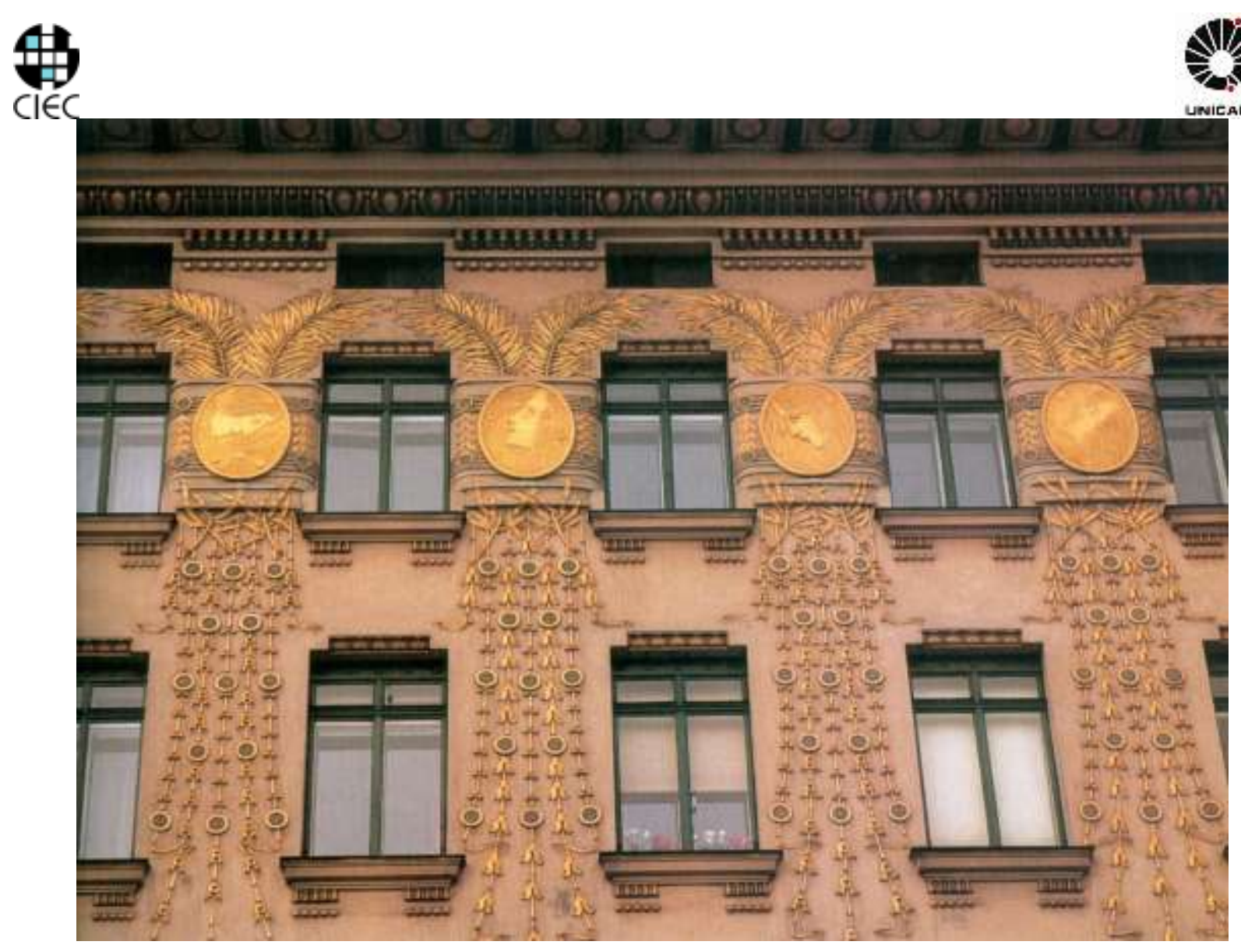

Figura 19: Majolika Haus, Viena. Projeto do arquiteto Otto Wagner, 1898-1899 - detalhe da fachada [M. Moore/Fotogram Stone] (Beyler, 1992, p. 39).

Wagner novamente apresentou-se em 1892, quando a municipalidade abriu um concurso para planos de expansão planejada da cidade, do qual deveria constar um desenho urbanístico unitário para os subúrbios recentemente anexados à Gross Wien. O ponto de maior atenção solicitado aos concorrentes recaia na rede viária e no transporte coletivo: organização do trânsito na parte central da cidade, reorganização da rede ferroviária metropolitana e remanejamento da rede de vias periféricas. Os projetos vencedores, apresentados pelas firmas de Otto Wagner e de Joseph Stübben, compartilharam o projeto executivo, não sem atritos, diz Calabi. Os aspectos técnicos e disciplinares couberam ao alemão Stübben e o controle estético e ambiental refinado ao austríaco Wagner que, por adotar a ideia de expansão ilimitada da cidade, propôs uma série de três cinturões concêntricos à Ring, atravessados por artérias radiais. 0 terceiro anel ganharia espaços verdes, parques, jardins e um pequeno porto fluvial (Calabi, 2000, p. 158-159). Wagner, autor do Manual de Arquitetura Moderna, de 1893, ao "exaltar o tecnológico e celebrá-lo como cultura" unia o primado da função para a determinação da forma, o uso de materiais modernos e o compromisso com a 
linguagem a-histórica e simbólica da modernidade. Seu lema manteve-se "a necessidade é a única senhora da arte" (Schorske, 1988, p. 95-101).

Embora Wagner não contemplasse em seu plano a distribuição das várias atividades no espaço urbano - moradia, indústria e comércio, escritórios -, o projeto executivo - "Bauzonenplan", aprovado em 1893, estabeleceu o princípio do zoneamento, com seis tipos de zonas caracterizadas pela diferente tipologia e altura dos edifícios. As bases da moderna arquitetura se expressaram nos prédios projetados por Wagner, ao despir as paredes exteriores de qualquer traço ornamental e trazer as janelas para o plano das paredes externas das casas aristocráticas e prédios de apartamentos. Tal como na Paris de Haussmann, a preocupação com a moradia operária não esteve no centro dos interesses das intervenções em Viena. As Mietkaserne (casas de aluguel) ${ }^{20}$ ofereceram o espetáculo monótono de prédios de vários andares nos bairros periféricos de Viena (Schorske, 1988, p. 65, 95). Novamente uma situação política veio definir o processo e se interpôs como o grande obstáculo para a execução mais completa do plano: a $1^{\text {a }}$ Guerra Mundial reduziu Viena a capital de um pequeno estado nação (Calabi, 2000, p. 159-160; Schorske, 1988, p. 88).

\section{Barcelona - Cerdà}

Paris é indissociável de Haussmann, Viena da Ringstrasse e da controvérsia entre Camillo Sitte e Otto Wagner, Barcelona por sua vez se mantém, com todas as ulteriores intervenções e certo desconforto para os barceloneses, vinculada ao nome de Cerdà e de uma decisão política autoritária. O desconforto se deve exatamente à forma impositiva do Ministério de Obras Públicas, do governo central de Madri, ao escolher o projeto do engenheiro Ildefonso Cerdà e desautorizar arbitrariamente a escolha pela municipalidade de Barcelona do arquiteto Antonio Rovira y Trias como vencedor, em 1858, do concurso para a expansão da cidade, concurso do qual o engenheiro Cerdà nem participara. A força da decisão política do decreto real de 1859 concedeu a Cerdà a execução do próprio plano, porém contribuiu bastante para o encobrimento e esquecimento secular de sua pessoa, e para formar a imagem de uma persona non

\footnotetext{
20 Wieczorek remete essa tipologia de habitação operária aos grandes prédios de seis andares (Familienhäuser) construídos, a partir de 1823 nos arredores de Hamburgo e Berlim, que abrigavam mais de 2.500 pessoas em 400 apartamentos de um cômodo. A exigüidade dos cômodos e corredores, a única latrina disponível para cada 50 pessoas, a ausência de esgotos e a impossibilidade de arejar as casas, resultaram em tão aguda falta de higiene nessas primeiras Mietskasern que chamaram a atenção das autoridades, especialmente quando, após 1831 as epidemias de cólera se sucederam nas cidades europeias (Wieczorek, 1981, p. 56-57).
} 
grata, uma espécie de profeta maldito. Aberasturi diz ter esse esquecimento sido suspenso somente por ocasião da Jornada do Urbanismo de 1959, consagrada ao Plano de Barcelona no ano do seu centenário, e Choay data em 1967 sua saída do ostracismo, centenário da publicação de sua Teoria General de la Urbanización (Aberasturi, 1979, p.19; Choay, 1980, p. 3).

Como na Áustria, o poder político conquistado pelos liberais progressistas, em 1854, por meio do "pronunciamento - Vicalvarada", concedera à cidade de Barcelona a possibilidade de insistir no pedido de demolição das muralhas impostas em 1719 por Filipe V. A justificativa recorria aos pressupostos das concepções higiênicas, já bastante difundidos, e apontava a ausência quase total de infraestrutura como responsável pela situação que tornava impossível evitar problemas sociais e sanitários. A despeito da iniciativa governamental para a construção de um bairro extramuros em terreno contíguo ao porto, o adensamento agudo e a taxa de mortalidade expunham uma situação assustadora - a média de vida da classe rica era de 38,83 anos e tornava-se mais precária para o trabalhador, 19,68 anos. Também em Barcelona os militares e os proprietários de edificações e terrenos intramuros resistiram, por motivos diferentes, à demolição das fortificações, porém essa posição mostrou-se pouco sustentável em vista dos problemas sociais e de higiene impeditivos do crescimento econômico da única cidade da Espanha com indústrias modernas. A ordem para a demolição das muralhas, publicada pelo diário oficial em 15 de agosto de 1854, daria início aos trabalhos acompanhados por grande festa popular (Aberasturi, 1979, p.13-18).

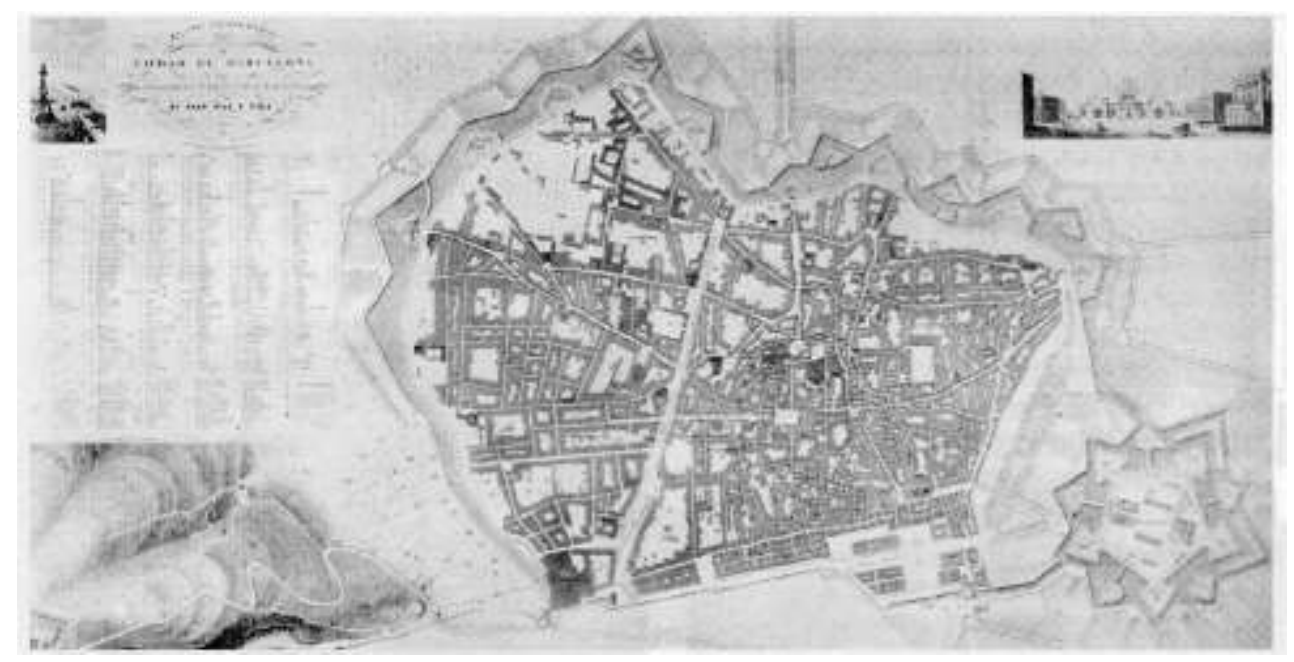

Figura 20: A antiga cidade murada de Barcelona no Plano geométrico de Josep Mas Vila, 1842 (Museu Histórico da Cidade) (Busquets, 2004, p. 115). 
Na ausência de plano para o traçado da expansão da cidade e inexistência de um plano topográfico de Barcelona contendo as vias e construções existentes, o Ministério de Obras Públicas encarregava para sua execução, em 1854, o engenheiro politécnico Cerdà, ex-aluno da Real Escuela de Caminos, Canales e Puertos de Madri. Pela municipalidade de Barcelona, uma comissão consultiva, formada com personalidades locais, sociedades artísticas, científicas e econômicas, por seu lado, definia as bases de um concurso público para a escolha de um projeto de urbanização para o qual se apresentaram 13 projetos. A $1^{\text {a }}$ colocação concedida ao arquiteto Antonio Rovira y Trias e desrespeitada pelo governo central, reabria a disputa política entre Madri e a rebelde e secularmente reprimida Barcelona. A indicação do engenheiro Cerdà acende, por sua vez, o debate no âmbito técnico acadêmico de disputa entre duas formações profissionais: os arquitetos que consideravam ser de sua competência um trabalho, para eles, eminentemente artístico e os engenheiros voltados para projetos de urbanização em termos racionais e funcionais modernos.

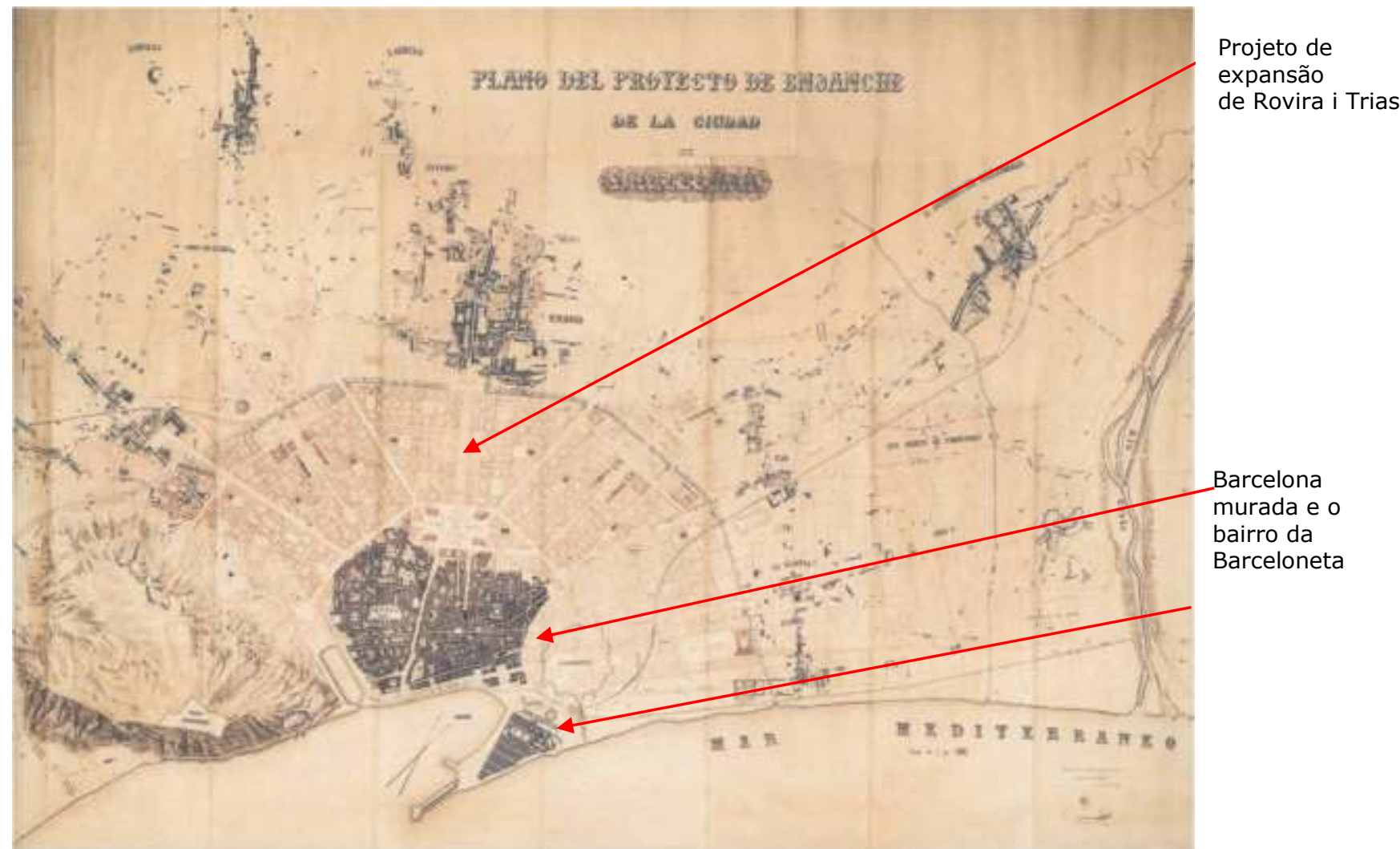

Figura 21: Plan de Ensanche [expansão] de Barcelona apresentado por Rovira i Trias, 1859. Projeto vencedor do concurso de projetos para a expansão da cidade aberto pela Municipalidade de Barcelona (Busquets, 2004, p. 125). 
Em clara demonstração da aceitação entre arquitetos da concepção da cidade como obra de arte coletiva, ao apresentar um projeto clássico e de grande beleza e apelo estético, Rovira afirmava vários anos antes de Camillo Sitte seu lema - "o traçado de uma cidade é antes obra do tempo do que do arquiteto. Propunha a organização da cidade a partir do entorno de uma grande praça central - fórum Isabel II - situada na junção da antiga e da nova aglomeração ordenada em anéis concêntricos da cabeça o fórum - aos membros periféricos, com as proporções de seus elementos moduladas pelas proporções do corpo humano, conforme os grandes tratados de arquitetura clássica, como o de Alberti ${ }^{21}$.

A projeção do espaço em leque com nítida divisão das classes sociais impõe uma forma altamente hierarquizada ao território: os rentistas e a nobreza próximos ao fórum, os burgueses nas grandes avenidas radiais próximas ao centro, porém não longe das fábricas localizadas no exterior; os operários nos bairros periféricos, próximos às fábricas; as outras classes sociais - comerciantes, empregados, etc. situados conforme seus rendimentos. Aberasturi afirma que a regra de segregação do plano Rovira consistia na tentativa de adaptação da arte urbana às necessidades da sociedade capitalista (Aberasturi, 1979, p. 22-23).

Cerdà trilhou o caminho bem mais ambicioso de fundador de uma nova disciplina "a urbanização", com o duplo sentido de conhecimento da condição atual do urbano e de disciplina normativa e operativa, designada depois como urbanismo. Formulou uma teoria com o que pretendeu serem "princípios da ciência urbanizadora" ou "ciência da urbanização", tendo por base as duas funções essenciais, movimento e moradia. Seu intuito consistia em conduzir a sociedade ao estágio de perfeição por meio da organização perfeita do espaço. A Teoria general de la Urbanización y aplicación de sus principios y doctrinas à la Reforma y Ensanche de Barcelona, publicados 3.000 exemplares dos dois primeiros volumes em 1867, não se limitou ao desenho e memorial do Plano de urbanização, já dado a público em 1863. Foi construída sobre cinco bases: A base técnica - as vias ou ruas urbanas, o conceito de rua, desenho da rede de vias, as ligações na rede de vias, os nós na rede de vias, os intervalos ou espaços isolados

\footnotetext{
${ }^{21}$ Para uma leitura conceitual da relação dos planos, em especial o de Cerdà, o trabalho mais detalhado e rigoroso é o de Françoise Choay - A regra e o modelo (1985, ed. francesa de 1980). Nela a autora analisa os textos dos tratados instauradores de regras para a arquitetura e as utopias definidoras de modelos fixos de cidades e seus seguidores e comentadores. Nele dedica espaço especial à leitura dos pressupostos de Cerdà nos longos livros de sua Teoría general de la urbanización, publicada em 1867, alguns anos após a apresentação do Plano de Expansão para Barcelona de 1857.
} 
na rede de vias; A base administrativa da urbanização, A base política da urbanização, A base legal da urbanização e A base econômica da urbanização (Cerdà-Puig, 2005, índice).

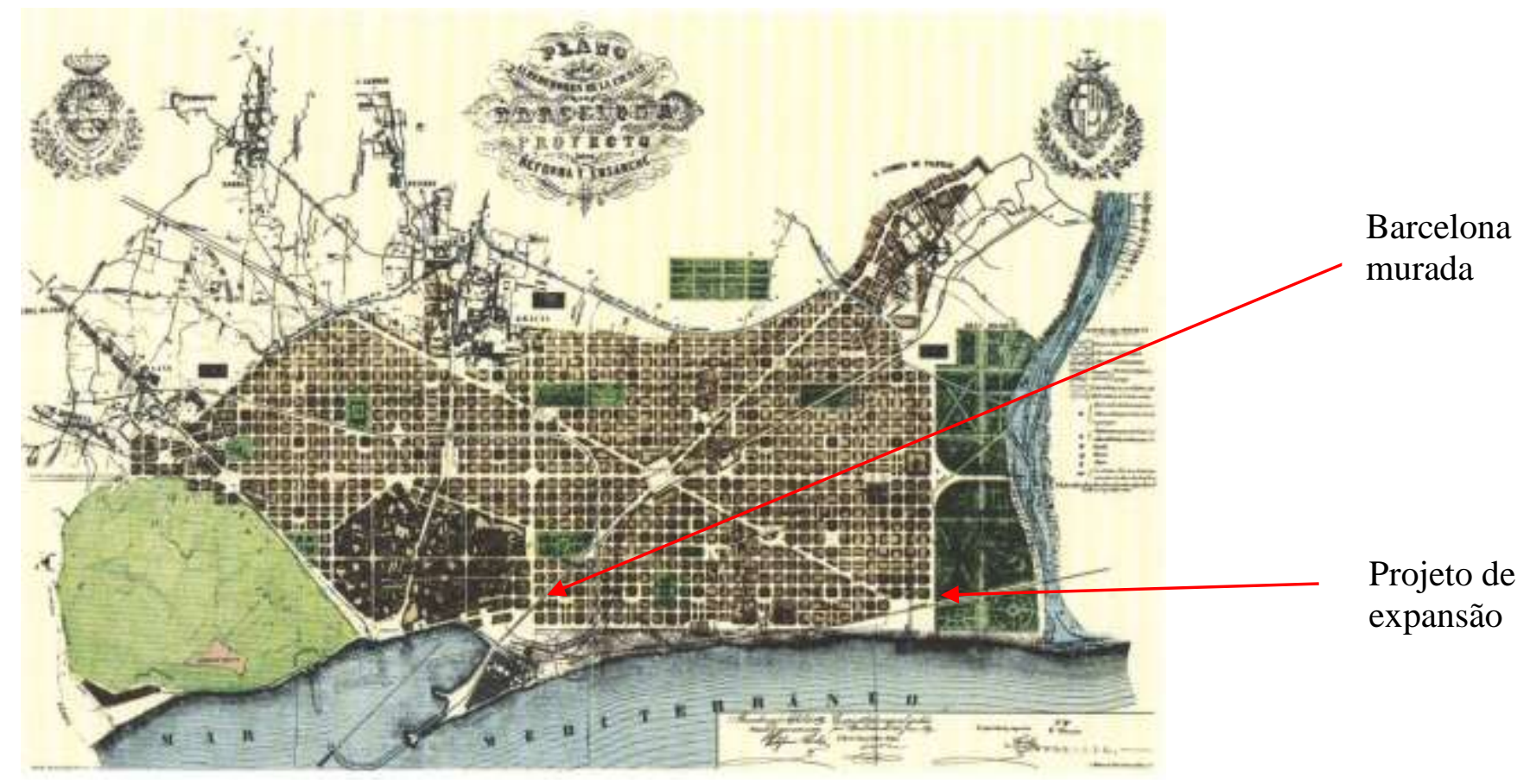

Figura 22: Plano de Ildefonso Cerdà para a expansão e reforma da cidade de Barcelona executado por encomenda do governo central de Madri e aprovado em 1859, reproduzido em Teoria general de la urbanización, publicado em Madri em 1867 (apud Vercelloni, 1996, planche 139).

No Prólogo do tomo II da Estatística urbana de Barcelona, Cerdà afirmava a generalidade das cidades suas contemporâneas, incluídas as das Américas por terem herdado vantagens e vícios das velhas cidades europeias, - "basta conhecer uma única para saber tudo das outras, pelo menos no que diz respeito aos seus elementos constitutivos" (Cerdà-Aberasturi, 1979, p. 183; Calabi, 2000, p. 41). Adepto de método interdisciplinar, recorreu à história e à biologia que lhe permitiram pensar a medicalização do urbano e afirmar o caráter científico do trabalho e da aplicação da noção do valor curativo do espaço. Contudo, a crítica social e o diagnóstico apresentado remetem para a busca de um modelo da utilização do espaço como verdadeiro disciplinador das práticas sociais e o aproxima de referências utópicas (Choay, 1985, p. 272-278). Uma citação de seu texto expressa bem a aproximação transdisciplinar:

(...) dediquei-me a estudar seus detalhes [da urbanização como um todo] uma tarefa anatômica na qual, pela inserção de um bisturi nas partes mais recônditas e íntimas do organismo urbano e social, foi possível captar, ao vivo 
unicamp e em ato, a causa original, a semente fecunda das graves enfermidades que corroem as entranhas da humanidade. Esse trabalho de dissecação ajudará, ao mesmo tempo, o leitor a entender como adquiri o conhecimento lúcido e exato das bases sobre as quais repousam os princípios da ciência da urbanização, as regras da arte a serem aplicadas (...) e a compreender a teoria e a técnica...22 (Cerdà-Puig, 1999, p. 75; tradução da autora).

Choay destaca a dimensão social da pesquisa de Cerdà e diz que o "observadorfilósofo, arrasta seu leitor para uma 'visita imaginária' graças a qual ele pintará o quadro dos traços patológicos da cidade contemporânea [...] a urbanização 'viciosa, corruptora, apolítica, imoral e anacrônica'", com "close-ups" de "tugúrios repugnantes e malsãos". Para ele, a habitação deixara de ser "o símbolo da morada do homem" e mais se assemelhava "ao antro de bestas feras" (Choay, 1985, p. 279). A atenção privilegiada dada às más condições das habitações, a dimensão da pesquisa e a forte ênfase social, diferencia-o e a seu plano dos planejadores e executores das reformas e extensão de Paris e Viena. Em Monografia estatística da classe operária de Barcelona, Cerdà propunha a diretriz para o planejamento:

Em todo projeto urbano, o urbanista deve buscar oferecer às famílias de todas as classes sociais o alojamento apropriado a seus respectivos modos de vida que, além de reunir as qualidades próprias da moradia moderna, tenha custo proporcional aos recursos de cada um. A moradia constitui a necessidade primeira do homem social, seja qual for a classe a qual pertença (CerdàAberasturi, 1979, p. 198, tradução da autora).

A longa e detalhada pesquisa lhe permitiu sistematizar os resultados com critérios numéricos, administrativos, sociais e culturais, e o autorizou a definir o objeto de sua disciplina a partir de dois polos operacionais: a habitação e a circulação. Para a expansão da Nova Barcelona, opôs o desenho da grelha à concepção radial concêntrica. Erradicava, assim, qualquer imagem cosmológica ou antropomórfica na justificativa do Plano e vinculava a natureza humana ao progresso técnico e científico na projeção da

\footnotetext{
22 Utilizei a versão em inglês da edição comentada da antologia de fragmentos da Teoria da Urbanização de Cerdà, de autoria de Arturo Soria Y Puig, com tradução de Bernard Miller (Cerdà, 1999). Puig afirma ter Cerdà publicado em vida unicamente os dois primeiros volumes da Teoria, os mais áridos de pesquisa, e terem permanecido nas gavetas da administração pública os memoriais dos projetos. Além de alguns panfletos, só recentemente se dispõe, não de toda sua obra, mas de cinco grandes volumes, os volumes I e II da Teoria e por vários apêndices inéditos (p. 46-47). Remeto também a Antonio Lopez de Aberasturi, organizador da primeira edição em francês de fragmentos da Teoria (Seuil, 1979), reeditada com revisão e vários apêndices contendo os debates da época do concurso (Les éditions de l'imprimeur, 2005).
} 
sociedade igualitária expressa na equivalência de todas as situações espaciais (CerdàAberasturi, 1979, p. 24-25, 52). A pesquisa monográfica sobre Barcelona, apresentada em quadros descritivos das situações encontradas e comprovada por estatísticas permitiu-Ihe basear a Teoria general de la urbanización na noção de higiene pública como postulado da defesa da opção pelo traçado de um imenso tabuleiro de xadrez, cuja função seria a de assegurar o máximo de facilidade para as comunicações e a independência do lar.

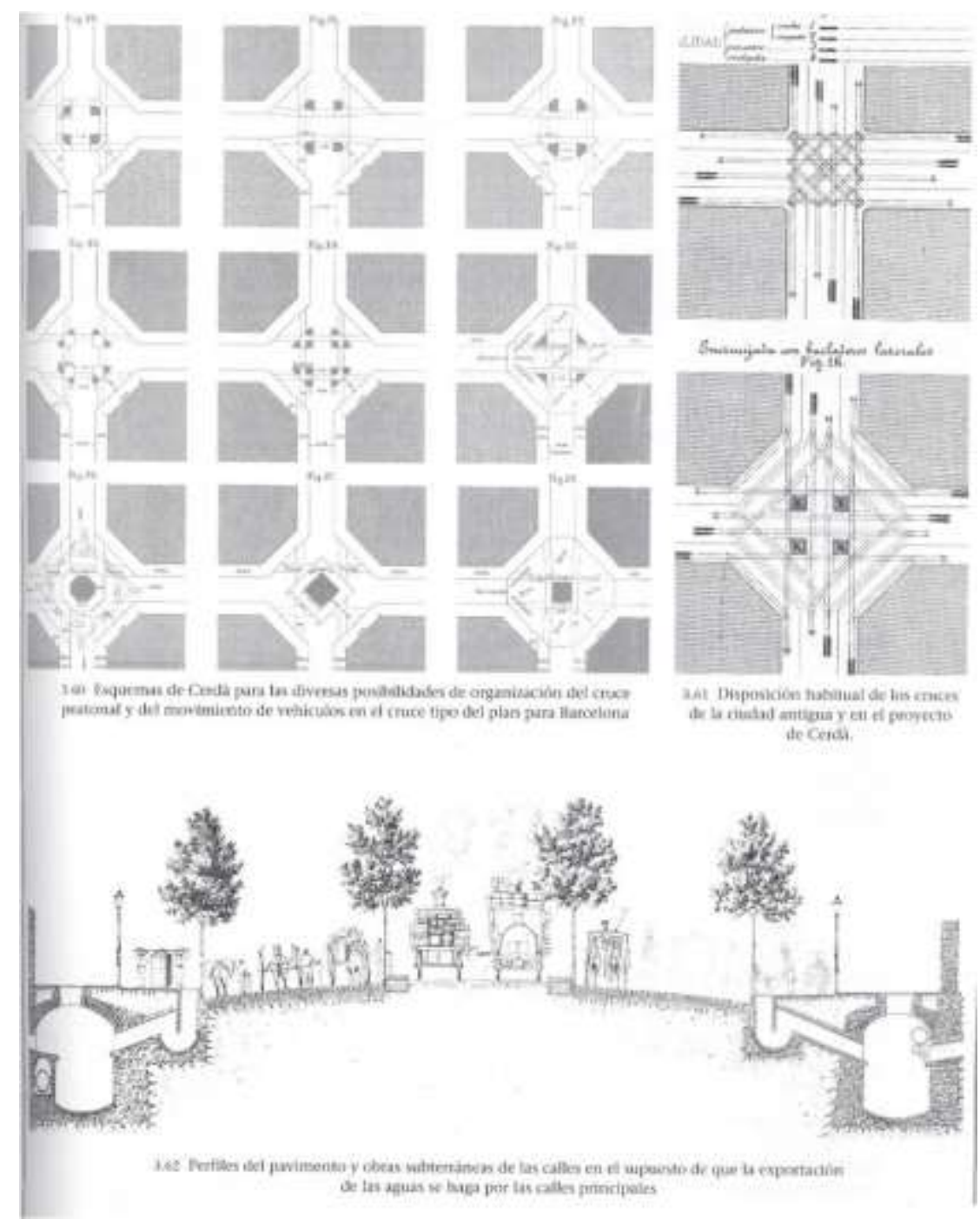

Figura 23: Esquemas de possíveis organizações de "intervias" [cruzamentos] com esquinas chanfradas e perfis do pavimento e das obras subterrâneas em ruas apresentados por Ildefonso Cerdá na Teoría General de la Urbanización, p. 363-364 (Busquets, 2004, p. 133). 

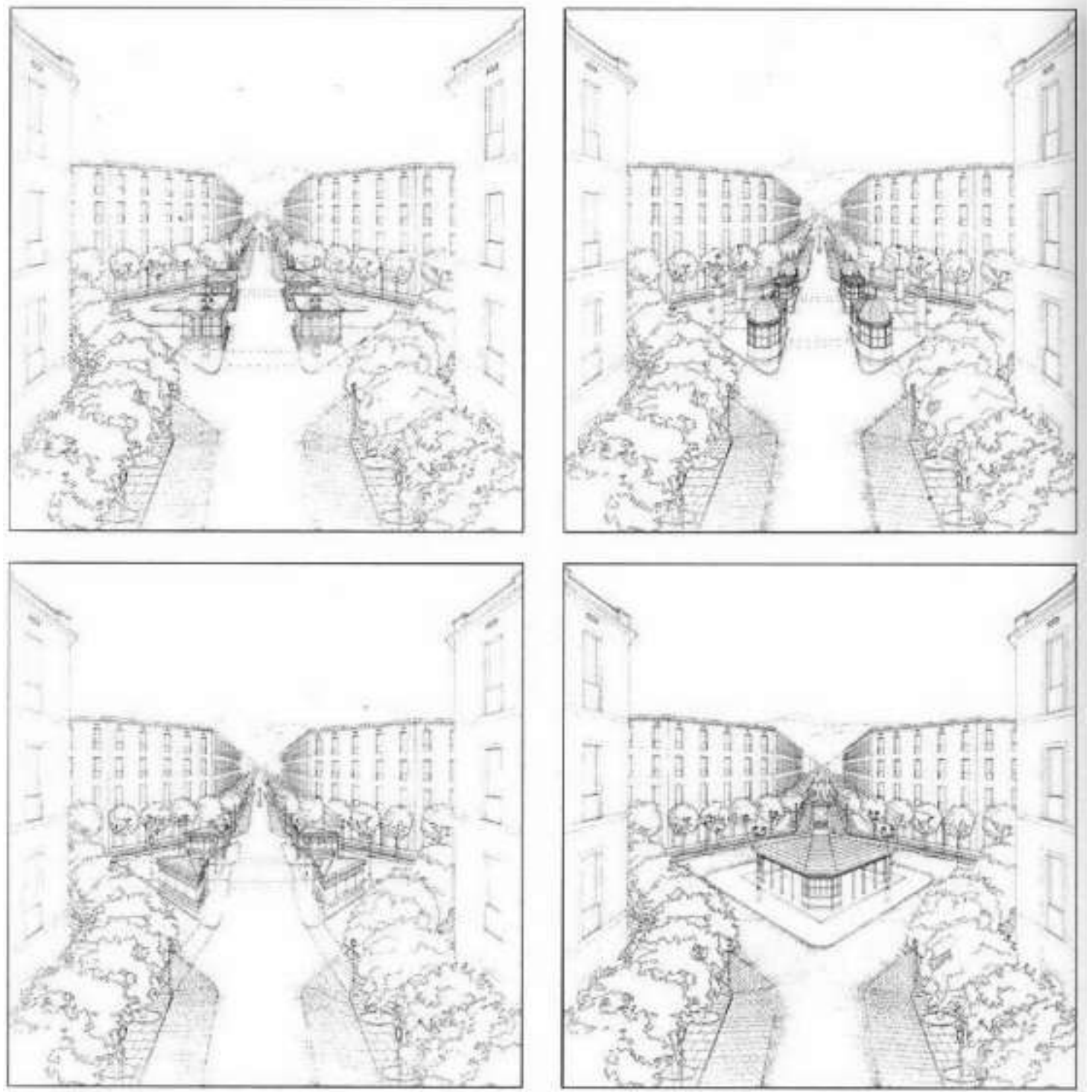

Figura 24: Alguns cruzamentos propostos por Cerdà e diversos tipos de quiosques e suas possíveis localizações. Desenhos de Fernando Alvarez. Exposição Cerdà. Urbs i Territori (Grupo 2C, 2009, p. Ixxviii).

Detalhou o posicionamento nas quadras dos conjuntos edificados, os respectivos programas de necessidades das moradias, as plantas e a cubagem de ar para cada um dos aposentos. Em resposta às críticas à grelha, reagiu ironicamente ao comentar os que, em sua opinião, desenhavam planos para uma cidade como se fosse "uma pintura geométrica recreativa" (Cerdà-Puig, 1999, p. 43). Seu plano provocou comentários sobre a semelhança entre o traçado da expansão de Barcelona e os planos em grelha de Nova York, Filadélfia e Buenos Aires. Contudo, deles se destaca pela abordagem conceitual em escala e estrutura diferenciadas: as vias e as quadras se dispõem em um "sistema" regular e homogêneo no intuito de assegurar a insolação nas casas, para as 
CIEC

ruas e avenidas define as larguras de $20 \mathrm{~m}$ e de $80 \mathrm{~m}$ para, respectivamente. Tal como ocorreu com a Ringstrasse em Viena, essas dimensões foram, na época, consideradas um exagero (Cerdà-Aberasturi, 1979, p. 22-25).

O critério matemático, preciso e irrefutável, adotado pelo engenheiro aparece no cuidado com o uso de termos na escrita, cuidado que mereceu anotação em seu diário: "nunca usar uma única palavra cujo verdadeiro significado etimológico seja desconhecido; nunca construir uma sentença não gramatical; nunca fazer um discurso sem submetê-lo a raciocínio apurado" (Cerdà-Puig, 2005, p. 25). A partir desse critério dispôs os equipamentos públicos sobre o traçado da área a ser urbanizada (ensanche): 1 centro social e religioso para cada 25 quadras, 1 mercado para cada 4, 1 parque para cada 8 e 1 hospital para cada 16, este, entretanto, situado fora da cidade. Acreditou desfazer a rigidez da grelha ao chanfrar as esquinas das quadras e adaptá-las melhor ao tráfico, ao entrecortá-la com espaços reservados ao lazer e propor a organização fantasiosa para cada grupo de quadras e com isso eliminar a rua corredor e tornar o conjunto construído independente do sistema viário (Cerdà-Aberasturi, 1979, p. 31).

O Plano matemático e a vontade férrea de Cerdà não impediram a resistência dos "vencidos" - a municipalidade barcelonesa, a corporação dos arquitetos, os proprietários da área interna e da área externa da cidade, a imprensa local, ou seja, "os que haviam aceito de má vontade" o plano imposto pelo governo de Madri. A política permaneceu o fiel da balança e, se a legislação reguladora da expansão da cidade (Fomento de Ensanches) proibia qualquer construção não prevista no Plano, esta foi modificada pelas leis de 1876 e de 1892 que, na prática, permitiram a legalização de todas as distorções cometidas pelos proprietários (Cerdà-Aberasturi, 1979, p. 43). Um ato político autoritário dera a Cerdà a oportunidade de propor um Plano de reforma e expansão para Barcelona, outros eventos políticos o afastaram e o trouxeram de volta: afastado após a revolução "Gloriosa" que destronou Isabel II em 1868, recolocado em 1873 quando o rei Amadeu de Sabóia pediu demissão do posto e as Cortes decidiram implantar uma república, cuja vida foi curta; afastado definitivamente em janeiro de 1874 quando, após as Cortes serem dissolvidas militarmente, uma ditadura provisória prepara a restauração do filho de Isabel, Afonso II. Esse retorno dos moderados ao poder marcaria um fim amargo à vida política e profissional de Cerdà. Por trágica ironia, o precursor do urbanismo e do planejamento modernos, que também, quase meio século antes de Patrick Geddes, mostrava a necessidade do survey preliminar (a 


\section{鱼}

pesquisa detalhada que fizera) para se formular qualquer plano de reforma ou expansão de cidades, morria em 1876, arruinado e difamado, enterrado na fossa comum de uma pequena aldeia, do outro lado da Espanha, na província de Santander. Aberasturi diz que, infelizmente a Barcelona atual afastou-se significativamente da idéia original do Plano impedindo, desse modo, qualquer avaliação objetiva (Cerdà-Aberasturi, 1979, p. 44-45).

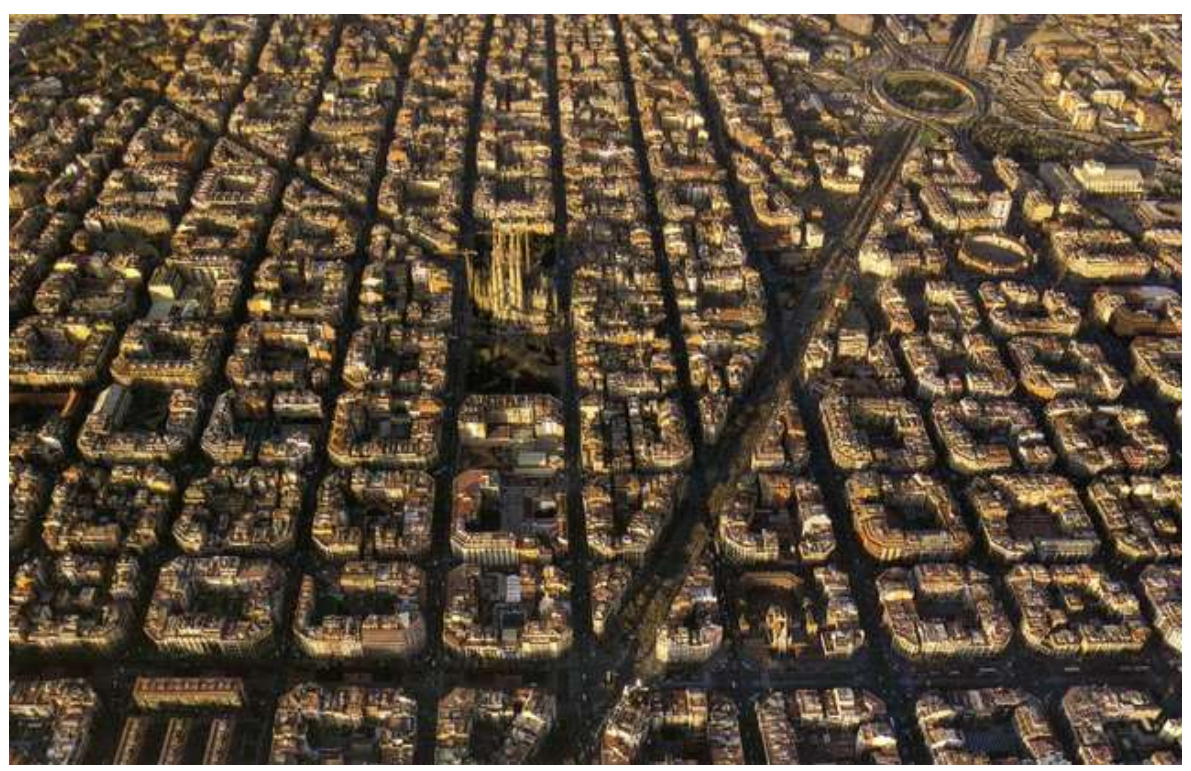

Figura 25: As quadras [manzanas] densificadas a partir das leis de 1876 e 1892 (disponível em umazocratto.blogspot.com. acesso em 21/05/2012).

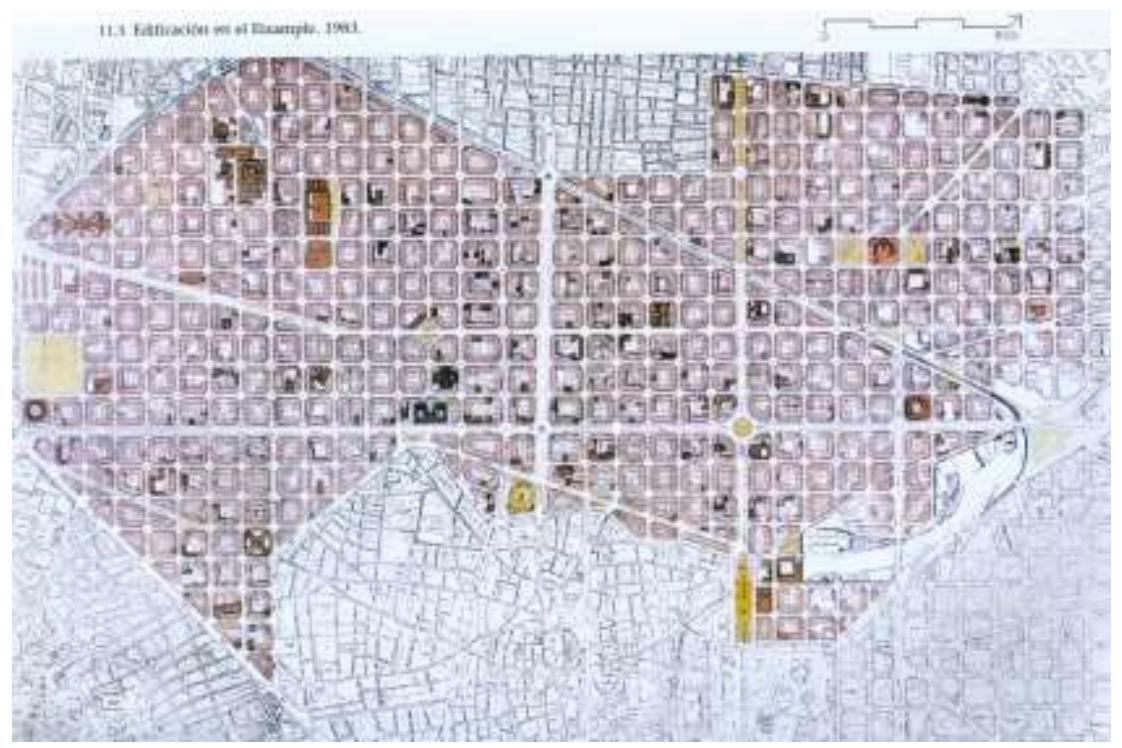

Figura 26: Mapa da edificação da área expandida de Barcelona [ 1983] na qual se vê a densificação das quadras "manzanas" já totalmente fechadas (Busquets, , 2004, imagem 11.3). 


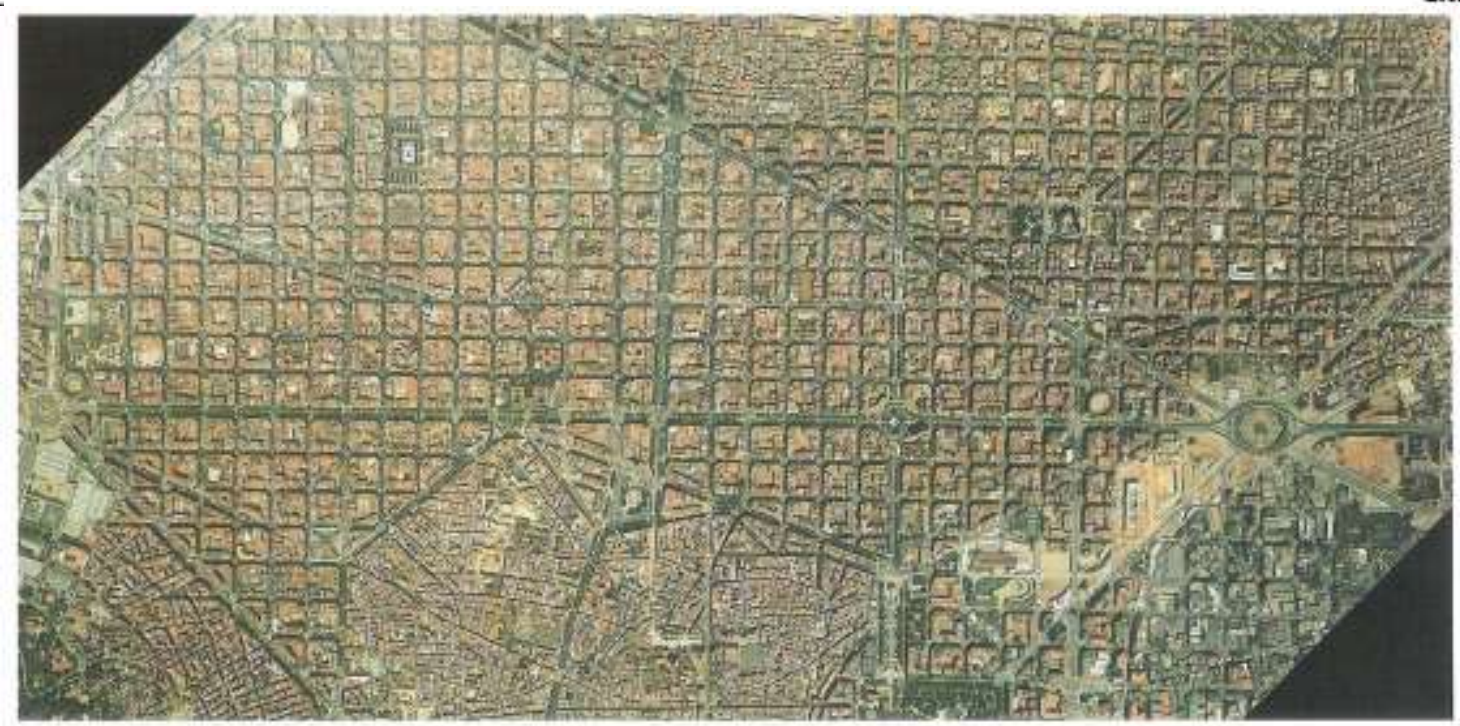

Figura 27: Imagem aérea de Barcelona em 2000 (Busquets, 2004, imagens 11.6 e 11.7).

\section{A difusão de uma área de atuação em formação}

A preocupação de Cerdà em tornar a grelha mais flexível aproximava-o de alguns de seus contemporâneos, como o paisagista norte-americano Frederick Law Olmested e sua crítica, nos anos de 1860, ao rígido xadrez de Nova York. O plano de construir o Central Park obedecia ao seu intuito de proporcionar um refúgio rural aos habitantes da cidade e dele fazer um ambiente de convívio entre pessoas de todas as classes sociais. A proposta visava recriar a comunidade cristã da Nova Inglaterra puritana. A crítica às cidades de seu país lançara o olhar do arquiteto para o passado, mas o mantivera atento às modernas teorias higienistas. Sua projeção da boa cidade não se dirigia, porém, para a idealização das formas das cidades medievais europeias, mas para o passado rural do país na proposta de formar subúrbios residenciais, refúgios domésticos nos quais os membros da comunidade pudessem interagir socialmente (Fairfield, 1993, p.18-21). Por sua vez, sua idealização de uma tipologia do rur in urbe, o aproximava dos já existentes grandes parques londrinos (Hyde Park aberto ao público em 1637, Saint James Park construído em 1684, Regent's Park em 1811) e ao posterior modelo de cidade jardim - town-country - proposto pelo inglês Ebenezer Howard, em 1898 (Ottoni, 1996, p. 13-15, 37-39) que dos subúrbios jardins de Olmested se diferencia pela concepção compreensiva de unidades urbanas dispostas como pequenas cidades nos arredores de grandes cidades, como Londres. Compostas de modo quase 
autárquico, circundadas por cinturões verdes, as cidades jardim estariam ligadas a outros centros por sistemas de trens de alta velocidade (Welter, 2002, p. 56).

Nessa sequência de linhas de reflexão e propostas de não limitar os planos de intervenção ao âmbito da cidade existente e das novas áreas a serem urbanizadas, considero elucidativo trazer mais detidamente o biólogo Patrick Geddes, que estudara em Paris na década de 1870, e sua Outlook Tower, ponto privilegiado para a visão ampla e compreensiva da cidade de Edimburgo, bem antes de Le Corbusier ter uma paisagem disposta frente aos olhos do alto da torre Eiffel em Paris. A torre de Geddes, montada com finalidade pedagógica dava a conhecer ao visitante, a cada andar, as várias fases da "evolução do organismo" urbano, expondo a concepção organicista das transformações urbanas, de largo uso, até hoje, em estudos de várias disciplinas acadêmicas baseados na noção de evolução.

O ensaio de Johann Wolfgang von Goethe (1790), no qual propunha uma explicação para a metamorfose das plantas, ofereceu a Geddes suporte para apresentar a aproximação, por homologia e analogia, entre a morfologia e o planejamento urbano e, segundo Welter, de modo "bem mais sofisticado do que a simples afirmação da cidade como entidade orgânica" (Welter, 2002, p. 3). Apoiado na teoria da evolução de Darwin e no ensaio de Goethe, Geddes vinculou os estudos das cidades a uma concepção evolucionista da história humana. Esta aproximação lhe permitiu inserir a noção de meio ambiente, como formador da diversidade das plantas e por analogia de todo e qualquer organismo. Na transposição da herança genética e cultural do homem para "unidade maiores, nacionais, raciais, religiosas", a cidade receberia a "experiência de cada geração passada de seus cidadãos" e formaria um específico genius loci, por ele referido como "o élan vital regional" (Welter, 2002, p. 92-96). A tríade - place, work e folk (lugar, trabalho, povo) - cobria, a seu ver, todas as atividades efetivas, bem como "pensamentos e sonhos" de cada grupo humano, e estabelecia os necessários vínculos com a geografia, a economia e a antropologia nos estudos da cidade (Welter, 2001, p. 31-33, 239). A ele se atribui também a primeira concepção do planejamento regional compreendendo o núcleo urbano, a área agrícola e demais atividades rurais e os pontos de conexão para o comércio com outros centros, na compreensão integrada da City of Life (Welter, 2002).

Tal como muitos de seus contemporâneos, Geddes participou de eventos nacionais e internacionais, viajou por vários países, dentre os quais, em estadias de 

trabalho, Paris, México, Índia e manteve amizade com vários de seus contemporâneos, como Bergson e Kropotkin (Tyrwhitt, 1949, p. 14). Seus conceitos urbanísticos foram traduzidos, por arquitetos, desenhistas e engenheiros, em projetos arquitetônicos. ${ }^{23}$ Os desdobramentos de seu trabalho são inúmeros e, evidentemente, merecem um estudo detido das formas pelas quais, apoiados explícita ou implicitamente em sua concepção organicista, estudiosos problematizaram a cidade no decorrer do século XX, dela fazendo campo de observação e laboratórios de experiências em intervenção urbana.

As trocas e diálogos, diretos ou não, entre profissionais de várias áreas e diversos países, as intervenções pautadas pelas teorias higienistas, técnicas sanitárias e preocupações estéticas junto a esses traços gerais de trajetórias profissionais aqui delineados, sugerem os começos plurais, em termos de áreas do conhecimento e de preceitos, até mesmo religiosos e moralizantes, bem como a dimensão transnacional complementar à composição transdisciplinar constituintes da área do urbanismo e do planejamento urbano e regional. Essas trocas, já bastante frequentes no final do séc. XIX e no período anterior à $1^{a}$ Guerra Mundial se mantêm no entre guerras, a despeito das graves e sensíveis questões políticas entre os países contendores. Seria certamente importante trazer exemplos de cidades da América latina, inclusive Brasil, que sofreram intervenções na segunda metade do século XIX e início do século XX.

Em percurso nada linear e permeado por conflitos e negociações, os princípios conceituais básicos formulados na segunda metade do século XIX e décadas iniciais do século XX se fazem presentes nas análises críticas das cidades de nossos dias, em suas ênfases nos problemas viários e sanitários, na insuficiência dos serviços de transporte coletivo, na carência de moradias adequadas para a população de baixa renda segregada em bairros periféricos ou em enclaves de favelas e cortiços intramuros. Esses princípios incitam, portanto, uma investigação e uma reflexão histórica sobre a constituição de um campo de conhecimento, noções e conceitos, utilizados em projetos e na ação de intervenções em núcleos urbanos constituídos ou planejamento de cidades. Encontram-se também nos debates de urbanistas e administradores públicos polarizados entre a concepção de cidade compacta ou de cidade dispersa, entre a cidade de crescimento ilimitado ou crescimento limitado por um cinturão verde, expandida por

\footnotetext{
${ }^{23}$ Cito como exemplos do trabalho conjunto de Geddes, o projeto da Universidade da Índia Central que contou com Frank C. Mears, o da Universidade Hebraica de Jerusalém com Avraham Melnikoff, Frank C. Mears e Benjamin Chaikin (Welter, 2002, p. 230-237)
}

REVISTA ELETRONICA DO CENTRO INTERDISCIPLINAR DE ESTUDOS SOBRE A CIDADE . ISSN 1982-0569 v. 7, n. 10, jan /ago (2015). Dossiê História Urbana: a configuração de um campo conceitual 
meio da polinucleação. Compõem, necessariamente, o(s) campo(s) conceitual(is) das análises e propostas dos pesquisadores que trouxemos para o debate na área da história. Sugerem, nem tão subliminarmente, minha compreensão da importância de nossa contribuição para que a disciplina história vá além de seu presente papel de base de eventos, sobre a qual pesquisadores dispõem sequências de projetos urbanísticos e arquitetônicos, ou sirva somente para apoiar instrumentalmente propostas de intervenções pontuais em área urbanas a serem "revitalizadas". Afinal, como diz o filósofo Luis Arenas, as metáforas comprometem e, a se considerar, no caso, da palavra "revitalizar", significam e nos fazem pensar, envolvem também "uma promessa de sentido que excede o alcance que seu usuário ou inventor pretendeu atribuir-lhe". Vão muito além "da mera figura retórica ou do simples adorno literário. As metáforas nos pensam" (Arenas, 2011, p. 76), ou seja, acrescentaria eu, são úteis, porém, induzem e limitam nossa reflexão pelo campo que recortam - impõem uma investigação.

\section{Referências bibliográficas}

ARENAS, Luis. Fantasmas de la vida moderna. Ampliaciones y quiebras del sujeto en ciudad contemporánea Madri: Editorial Trotta. 2011.

ARGAN, Giulio Carlo. História da arte como história da cidade. São Paulo: Martins Fontes. 1993.

BAUMEISTER, Reinhard. L'espansione urbana nei suoi aspetti tecnici, legislative ed economici, berlim (1876). In Piccinato, Giorgio. La costruzione dell'urbanistica. Germania 1871-1914. Roma: Officina Edizioni. p. 187-256. 1974.

BEGUIN, François. As maquinarias inglesas do conforto. Espaços e Debates. São Paulo, n. 34, p. 39-54.1991.

BENTHAM, Jeremy. Panopticon; or The Inspection-House. In: Bozovic, Miran (Ed.). The Panopticon Writings. Londres/Nova York: Verso. p. 29-95. 1995 [ed. original de 1787].

BEYLER, Jean-Noël. L'Architecture au 19e siècle. Beaux Arts Magazine, Paris, Publications Nuit et jours. 1992.

BLAIS, Marie-Claude. La solidarité. Histoire d'une idée. Paris: Gallimard. 2007.

BOYER, Christine. The City of Collective Memory. Its Historical Imagery and Architectural Entertainments. Cambridge/Massachusetts/Londres: MIT Press. 1966. 
BRESCIANI, Maria Stella. Cidade e território: os desafios da contemporaneidade numa perspectiva Histórica. In: Pontual, Virginia e Loretto; Piccolo, Rosane (Org.). Cidade, Território e Urbanismo. Um campo conceitual em construção. Recife: CECI. p. 119140. 2009.

Paulo: Brasiliense. 1982.

Londres e Paris no século XIX: espetáculo da pobreza. São

BUSQUETS, Joan. Barcelona: la construcción de uma ciudad compacta. Barcelona: Serbal. 2004.

CALABI, Donatella. Storia dell'urbanistica europea. Questioni, strumenti, casi esemplari, Turim: Paravia Bruno Mondadori Editori. 2000.

. Marcel Poëte et le Paris des années vingt : aux origines de « I'histoire de villes », Paris-Canada : L'Harmanttan, 1997.

CARS, Jean des; Pinon, Pierre. Paris-Haussmann. Paris: Éditions Du Pavillon de I'Arsenal/Picard Éditeur. 1991.

CERDA, Ildefonso. La théorie générale de I'Urbanisation. Paris: Seuil. 1979.

CHADYCH, Danielle; Leborgne, Dominique. Atlas de Paris. Evolution d'un paysage urbain, Paris: Parigramme. 1999.

CHAMBELLAND, Colette (Org.) Le Musée social en son temps. Paris: Presses de I'École Normale Supérieure. 1998.

CHEVALIER, Jacques (Org.) La Solidarité, un sentiment républicain? Paris: PUF. 1992.

CHOAY, Françoise. O Urbanismo. Utopias e Realidade. Uma Antologia. São Paulo: Perspectiva. 1997.

São Paulo: Perspectiva. 1985.

A regra e o modelo. Sobre a teoria da arquitetura e do urbanismo.

COLLINS, Christiane Crasemann. Werner Hegemann and the Search for Universal Urbanism. Nova York/Londres: W. W. Norton \& Company. 2005.

COLLINS, Geroge R.; Crhistiane Crasemann. Camillo Sitte: The Birth of Modern City Planning. Mineola: Dover Publications, Inc. 2006.

DAVIS, Mike. Planets of Slums. Londres/Nova York: Verso. 2006.

ESTAPÉ, Fabián. Vida y obra de Ildefonso Cerdà. Barcelon: Península. 1971.

Dossiê São Paulo, hoje. Estudos Avançados - USP, São Paulo, v. 25, n. 71. jan.-abr. 2011. 
CIEC

FAIRFIELD, John D. The Mysteries of the Great City. The Politics of Urban Design. 18771937. Columbus: Ohio State University Press. 1993.

GRUPO 2C. La Barcelona de Cerdà, Barcelona: Flor Del Viento Ediciones. 2009.

GEDDES, Patrick. Cidades em evolução. Campinas: Papirus. 1994.

CORREIA, Telma de Barros (Org.). Philip Gunn. Debates e proposições em arquitetura, urbanismo e território na era industrial. São Paulo: Fapesp/Annablume. 2009.

HAYWARD, J. E. S. Solidarity: The Social History of An Idea in Nineteenth Century France. International Review of Social History, Cambridge University Press, v. 4, p. 261284. 1956.

. The Official Social Philosophy of the French Third Republic: Léon Bourgeois and Solidarism. International Review of Social History, Cambridge University Press, v. 6, p. 19-48. 1961.

HIMMELFARB, Gertrude. The Idea of Poverty. England in the Early Industrial Age. New York: Vintage Books Ed. 1985.

HORNE, Janet. Le Musée social. Aux origines de I'État providence. Paris: Belin. 2004.

MAIA, Francisco Prestes. Estudo de um Plano de Avenidas para a Cidade de São Paulo. São Paulo: Companhia Melhoramentos de São Paulo. 1930.

MAIA, Francisco Prestes. Os melhoramentos de São Paulo. São Paulo: Prefeiura Municipal. 1945.

Publicações Associadas. 1942.

São Paulo, Metrópole do Século XX. São Paulo: Empresas de . O Zoneamento Urbano. São Paulo: Sociedade Amigos da

Cidade. 1936.

Mello, Luis de Anhaia. Um Plano Regulador para o Município. Orientação Planológica e a Organização Administrativa. Revista de Engenharia, v. 39, vol. IV. nov. de 1945.

Paulo, v. XVIII, n. 91. jun. de 1933.

A cidade cellular. Boletim do Instituto de Engenharia, São . Problemas de Urbanismo. O recreio activo e organisado das cidades modernas. São Paulo: Escolas Profissionaes Salesianas. 1929.

O Governo das Cidades. In: Problemas de urbanismo. Bases para a resolução do problema technico. São Paulo: Escolas Profissionaes Salesianas. 1928.

NOVAES, Washington. A lógica da inércia e a perda do essencial. O Estado de São Paulo, São Paulo, Caderno A, p. 2. 15 jul. 2011. 
OBLET, Thierry. Gouverner la ville. Paris: PUF. 2005.

OTTONI, Dacio A. B.; Ebenezer Howard. Cidades-Jardins de amanhã. São Paulo: Hicitec. 1996.

PICCINATO, Giorgio. La costruzione dell'urbanista. Germania 1871-1914. Roma: Officina Edizioni. 1974. [Antologia de escritos de Reinhard Baumeister, Joseph Stübben, Cronelius Gurlitt e Rud Eberstadt aos cuidados de Donatella Calabi].

PIZZA, Antonio; Rovira, Josep (Ed.). M.G.A.T.C.P.A.C. - Una nueva arquitectura para una nueva ciudad/A new architecture for a new city. 1918-1939. Barcelona: Collegi d'Arquitectes de Catalunya. 2006.

PUIG, Arturo Soria y. Cerda. The Five Bases of the General Theory of Urbanization. Barcelona: Electa. 1999.

REIS, Nestor Goulart. Notas sobre Urbanização dispersa e novas formas de tecido urbano. São Paulo: Via das Artes. 2006.

RIBEIRO, Wagner Costa. Oferta e estresse hídrico na Região Metropolitana de São Paulo. Estudos Avançados - USP, São Paulo, v. 25, n. 71, p. 119-133. jan.-abr. 2011.

ROCHARD, Jules. Encyclopédie d'Hygiène et de Médicine Publique. Paris: Lecrosnier et Babè, Libraires-Éditeurs. 1891.

ROLNIK, Raquel e Klintowitz, Danielle. (I)Mobilidade na cidade de São Paulo. Estudos Avançados - USP, v. 25, n. 71, p. 89-108. jan.-abr. 2011.

ROSSETTI, Carolina; Marsiglia, Ivan. Horizontes Urbanos. Os dilemas e os rumos da metrópole que potencializa os problemas das principais cidades brasileiras. O Estado de São Paulo, São Paulo. Caderno Aliás, p. J4-J5.19 jun. 2011.

SECCHI, Bernardo. Primeira lição de urbanismo. São Paulo: Perspeciva. 2006 [edição italiana Roma-Bari: Gius.Laterza \& Figli. 2000].

2006.

. La città del ventesimo secolo. Roma-Bari: Gius.Laterza \& Figli. 2005,

Schorske, E. Carl. De Vienne et d'ailleurs. Figures culturelles de la modernité. Paris: Fayard. 2000.

Letras. 1988.

- Viena fin-de siècle. Política e Cultura, São Paulo: Companhia das

SITTE, Camillo. City Planning according to artistic principles. A contribution to the solution of modern problems of Architecture and Monumental Sculpture especially with regard to the City of Vienna. Vienna: Verlag von Carl Graeser, 1889 (traduzido do alemão para o inglês por George R. Collins e Christiane Crasemann Collins, Mineola/Nova York: Dover Publications Inc. 1986). 
STÜBBEN, Joseph. L'urbanistica, manual d'architettura, Darmstadt, 1890. In : Piccinato, Giorgio. La costruzione dell'urbanistica. Germania 1871-1914. Roma: Officina Edizione. p. 257-370. 1974.

TOPALOV, Christian (Org.). Laboratoires du nouveau siècle. La nébuleuse réformatrice et ses réseaux en France, 1880-1914. Paris: École des Hautes Études en Sciences Sociales. 1999.

TYRWHITT, Jaqueline. Introdução a Patrick Geddes. Cidades em Evolução. Campinas: Papirus. 1994.

VERCELLONI, Virgilio. La Cité idéale en Occident. Paris: Philippe Lebaud. 1996.

VITRUVIUS (versão em inglês Hicky Morgan). The ten books on Architecture. Nova York: Dover Publications, Inc., 1960.

WAGNER, Otto. Esquises - Projets - Constructions. Liège/Burxelas: Pierre Madraga Editeur. 1987.

WELTER, Volker M. Biopolis. Patrick Geddes and the City of Life. Cambridge-Londres: The MIT Press. 2002.

WIECZORECK, Daniel. Camillo Sitte et les débuts de l'urbanisme moderne. BurxelasLiège: Pierre Madraga ed. 1981.

ZUCCONI, Guido (Org.) Camillo Sitte e i suoi interpreti. Milão: Franco Angeli. 1992. 